\title{
HIGH TECHNOLOGY ENTREPRENEURS AND THE PATENT System: RESUlTS OF THE 2008 BERKELEy PATENT SURVEY
}

\author{
Stuart J.H. Grabam, ${ }^{\dagger}$ Robert P. Merges, "t Pam Samuelson, ${ }^{\text {tht }}$ \& Ted Sichelman ${ }^{\text {tht }}$
}

\begin{abstract}
We offer description and analysis of the 2008 Berkeley Patent Surveythe first comprehensive survey of patenting and entrepreneurship in the United States-summarizing the responses of 1,332 early-stage technology companies founded since 1998. Our results show that entrepreneurs have varied and subtle reasons for using the patent system, many of which diverge from the traditional theory that patents provide an "incentive to invent." Somewhat surprisingly, startup executives report that patents generally provide relatively weak incentives to conduct innovative activities. But while a substantial share of early-stage companies hold no patents, we also find that holding patents is more widespread than previously reported, with patenting patterns and motives being highly industry, technology, and context specific. When early-stage companies patent, they are often seeking competitive advantage, and the associated goals of preventing technology copying, securing financing, and enhancing reputation. We find substantial differences between the health-related sectors (biotechnology and medical devices), in which patents are more commonly used and considered important, and the software and Internet fields, in which patents are reported to be less useful. Startups with venture funding hold more patents regardless of industry, although unlike software companies, venture-backed IT hardware firms show a patenting pattern more similar to that of health-related firms. When choosing not to patent major innovations, early-stage companies often cite to cost considerations, and report substantially higher patenting costs than the
\end{abstract}

Sichelman.

(C) 2009 Stuart J.H. Graham, Robert P. Merges, Pam Samuelson, and Ted

$\dagger$ Assistant Professor, Georgia Institute of Technology, College of Management \& Affiliated Scholar, Berkeley Center for Law and Technology, University of California, Berkeley, School of Law.

H Wilson Sonsini Goodrich \& Rosati Professor of Law and Technology, University of California, Berkeley, School of Law.

HI Richard M. Sherman Distinguished Professor of Law, University of California, Berkeley, School of Law.

HI Assistant Professor, University of San Diego, School of Law \& Affiliated Scholar, Berkeley Center for Law and Technology, University of California, Berkeley, School of Law. 
prior literature has estimated. Our unique findings help inform the ongoing debate about the role and usefulness of the patent system.

\section{TABLE OF CONTENTS}

I. INTRODUCTION: WHY INVESTIGATE HOW ENTREPRENEURS USE (AND ARE AFFECTED BY) THE PATENT SYSTEM?

II. . APPROACH TO SURVEYING HIGH TECHNOLOGY ENTREPRENEURS ABOUT THEIR USE OF IP

A. OUR FOCUS IS ON TECHNOLOGY STARTUPS 1266

1. Targeting "Entrepreneurial Companies" and Their Top Executives.

2. Selecting High Technology Sectors................................................... 1268

3. Choosing Companies to Survey ....................................................... 1269

B. PRofILING OUR RESPONDENT COMPANIES ..................................... 1271

III. PATENT (AND APPLICATION) HOLDING IN TECHNOLOGY STARTUPS.

A. PATENT HOLDING AMONG STARTUPS Is WIDESPREAD BUT NOT UBIQUITOUS.

1. Startups' Patents Come from Several Different Sources 1274

2. Startups Hold Numerous Patents, but Explanations Are Nuanced.

3. Technology Entrepreneurs Suggest the Patenting Story Is Complex.

B. In PATENTING, Not ALL STARTUPS ARE CREATED EQUAL ......... 1278

1. Industry Influences the Incidence of Startups Holding Patents............. 1278

2. Venture-Backed Companies Are More Likely to Hold Patents ....... 1279

C. PATENTS MAY OfFER ONLY MIXED TO WEAK INCENTIVES

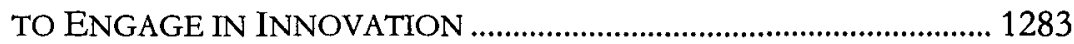

1. The Reported Relatively Weak Incentive Value of Patents................ 1285

2. The Multiple Meanings of Startup Patenting. 1287

IV. FIRST FINDING: PATENTS HELP STARTUPS IN TECHNOLOGICAL COMPETITION

A. Patents Can Serve to Promote Startups'

COMPETITIVE ADVANTAGE 1288

1. Industry Influences Patents' Role in Competitive Advantage ............. 1290

2. Patents' Role in Technology Competition Differs by Innovation Focus.

3. Startups Use Multiple Methods to Compete with Technology Innovations 
V. SECOND FINDING: STARTUPS HAVE DIFFERING MOTIVES FOR PATENTING 1296

A. Startups File Paten'ts to PREVENT Copying, SECURE FINANCIAL GOALS, AND ENHANCE REPUTATION

B. StaRtuPS' MOtTVATIONS TO SEEK PATENTS DIFFER BY INDUSTRY 1302

C. PATENTS SERVE AN IMPORTANT FUNCTION IN THE

FINANCING OF STARTUPS 1303

1. Investors and Entrepreneurs Highlight the Role of Patents in Startup Financing.

2. The Role of Patents in Attracting Entrepreneurial Capital. 1306

a) Startups Report That Patents Are Important to Their Investors................................................................ 1306

b) Patents' Reported Importance to Investors Differs by Industry. 1308

VI. THIRD FINDING: TECHNOLOGY ENTREPRENEURS VARY IN THEIR REASONS FOR NOT SEEKING PATENTS 1309

A. COST CONSIDERATIONS LOOM LARGE FOR STARTUPS IN DECIDING TO FORGO PATENTING 1310

B. STARTUPS' REASONS TO FORGO PATENTING DIFFER BY INDUSTRY

1. Biotechnology Startups Most Commonly Cite Reluctance to Disclose Information as a Reason Not to Patent. 1312

2. Software and Internet Startups Most Commonly Cite Cost Considerations as a Reason Not to Patent.

3. The Most Important Reason Not to Patent Also Differs by Industry 1314

C. Startups' Motives to Forgo Patenting DifFer by INNOVATION TYPE

VII. TECHNOLOGY ENTREPRENEURS MUST RECKON WITH PATENTS HELD BY OTHERS

A. LICENSING-IN PATENTS: (SOME) STARTUPS LICENSE FROM OTHER PATENT-HOLDERS

1. Startups License Both to Gain Knowledge and to Settle Disputes..... 1317

2. Venture-Backed IT Startups Take More Patent Licenses 1318

B. CHECKING THE PATENT LitERATURE BY STARTUPS: MiXED FINDINGS

VIII. IS THE PATENT SYSTEM WORKING FOR U.S. TECHNOLOGY STARTUPS?

IX. CONCLUSION 


\section{INTRODUCTION: WHY INVESTIGATE HOW ENTREPRENEURS USE (AND ARE AFFECTED BY) THE PATENT SYSTEM?}

Entrepreneurs contribute significantly to economic growth in the U.S. and global economy. 'They create new organizations, products, services, jobs, and opportunities for complementary economic activities. ${ }^{2}$ Intellectual property (IP) law is an important policy lever that affects not only the opportunities for engaging in entrepreneurship, but also the success or failure of many entrepreneurial efforts. ${ }^{3}$

Classical economic theory holds that investments in technology development-of which entrepreneurial activities are an integral part-will be suboptimal if too little intellectual property protection exists. ${ }^{4}$ However,

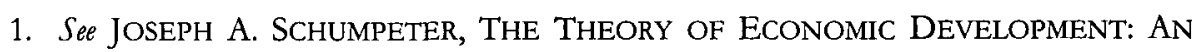
INQUIRY INTO Profits, CAPITAL, CREDIT, INTEREST, AND THE BuSINESS CyClE 74-94 (1934) (examining the role that entrepreneurship plays in the dynamism of capitalist economies); ZOLTAN ACS \& DAVID AUDRETSCH, INNOVATION AND SMALL. FIRMS 19-24 (1990) (discussing innovation rates among large and small firms); DAVID B. AUDRETSCH, MAX C. KEIlbaCH \& ERIK E. LEHMANN, ENTREPRENEURSHIP AND ECONOMIC GROWTH (2006) (examining the relationship between entrepreneurship and economic growth); ANDRÉ VAN STEL, EMPIRICAL ANALYSIS OF ENTREPRENEURSHIP AND ECONOMIC GROWTH (2006) (same as above); John C. Bound et al., Who Does R\&D and Who Patents?, in R\&D, PATENTS AND PRODUCTIVITY 21 (Zvi Griliches ed., 1984); Martin A. Carree \& A. Roy Thurik, The Impact of Entrepreneurship on Economic Growth, in HANDBOOK OF ENTREPRENEURSHIP RESEARCH 437 (Zoltan J. Acs \& David B. Audretsch eds., 2003) (examining the relationship between entrepreneurship and economic growth); Samuel Kortum \& Josh Lerner, Assessing the Contribution of Venture Capital to Innovation, 31 RAND J. ECON. 674, 682 (2000) (examining the systematic measurement of the relationship between venture capital and innovation).

2. See supra note 1. See generally Ingrid Verheul et al., An Eclectic Theory of Entrepreneurship: Policies, Institutions and Culture, in ENTREPRENEURSHIP: DETERMINANTS AND POLICY IN A EUROPEAN-US COMPARISON 11, 18 (2002) (describing the supply and demand for entrepreneurial activity, including culture; industry structure; individual attributes; and technological, market, and financing opportunities).

3. See David H. Hsu \& Rosemarie Ziedonis, Patents as Quality Signals for Entrepreneurial Ventures 2 (Apr. 2007) (unpublished manuscript, on file with the Mack Ctr. for Technological Innovation) (finding that a doubling in the patent stock of venture-backed semiconductor companies leads to a $24 \%$ premium in market valuation); see also Andreas Panagopoulos \& In-Uck Park, Patent Protection, Takeovers, and Startup Innovation: A Dynamic Approach 19 (Ctr. for Mkt. \& Pub. Org., Working Paper No. 08/201, 2008), available at http://www.epip.eu/conferences/epip03/papers/Panagopoulos_ip-aug08v2-sw.pdf (providing an economic model wherein "positive but not excessive IP protection" leads to increased acquisitions of startup firms by incumbents, thereby increasing overall innovation); Ted Sichelman, Commercializing Patents, 62 STAN. L. REV. 341 (2010) (exploring the relationship between patent protection and the successful commercialization of invention).

4. See generally William D. Nordhaus, InVEntion, GrowTH, AND Welfare: A Theoretical TREatment OF TeCHNOLOGICAL CHANGe (1969) (discussing the standard economic theory of IP); Kenneth J. Arrow, Economic Welfare and the Allocation of Resources for 
because entrepreneurial activity may be redirected or halted by intellectual property rights claimed by others, an equally serious impediment to investment for entrepreneurs may arise if IP protection is too strong or uncertain. $^{5}$

Although a considerable body of previous work has explored the relationship between IP rights and innovation, far less scholarship has focused on the more particular relationship between IP rights and entrepreneurship. ${ }^{6}$ The basic economic principle underlying IP rights is that the process of developing innovative products and practices is an expensive, time-consuming, labor-intensive, and risky endeavor. ${ }^{7}$ Once these innovations exist, however, they can be cheap and easy to copy. ${ }^{8} \mathrm{IP}$ rights protect innovators from copying by free riders and allow them to recoup the investment incurred during the creation, development, and commercialization processes, either directly by manufacturing and distributing products and services embodying the innovation, or indirectly through licensing to other firms that incorporate the innovation in their products and services. ${ }^{9}$ Although this basic economic principle applies to all companies, because early-stage firms tend to lack the kinds of complementary assets (such as well-defined marketing channels, manufacturing capabilities, and access to cheap credit) that ease entry into the market, they are arguably even more sensitive to IP rights than their more mature counterparts. ${ }^{10}$ Nevertheless, research and policy analysis has not

Innovation, in THE RATE AND DIRECTION OF INVENTIVE ACTIVITY: ECONOMIC AND SOCIAL FACTORS 609 (William D. Nordhaus ed., 1962) (same as above).

5. See Stuart J.H. Graham \& Ted Sichelman, Why Do Start-Ups Patent?, 23 BERKELEY TECH. L.J. 1063, 1080-81 (2008) (exploring how incumbents may use patent portfolios to restrain startups from entering markets); Colleen V. Chien, Of Trolls, Davids, Goliaths, and Kings: Narratives and Evidence in the Litigation of High-Tech Patents, 87 N.C. L. REV. 1571, 157374 (2009).

6. See, e.g., NORDHAUS, supra note 4; Arrow, supra note 4; Lee G. Branstetter, Raymond Fisman \& C. Fritz Foley, Do Stronger Intellectual Property Rights Increase International Technology Transfer? Empirical Evidence from U.S. Firm-Level Panel Data, 121 Q.J. ECON. 321 (2006); Nancy Gallini \& Suzanne Scotchmer, Intellectual Property: When Is It the Best Incentive System?, 2 INNOVATION POL'Y \& ECON. 51 (2002); Elhanan Helpman, Innovation, Imitation, and Intellectual Property Rights, 61 ECONOMETRICA 1247 (1993).

7. Arrow, supra note 4 , at 619.

8. Id. at 614

9. Concerning these latter transactions in the markets for technology, see ASHISH ARora, ANDREA FoSFuri \& AlFONSO Gambardella, MARKETS FOr TECHNOlogy: THE ECONOMICS OF INNOVATION AND CORPORATE STRATEGY 171-96 (2004).

10. See Scott Shane, Technological Opportunities and New Firm Creation, 47 MGMT. SCI. 205, 209 (2001) ("Although established firms might also be more likely to commercialize broad patents, they are disproportionately important to independent entrepreneurs who lack complementary assets."). See generally David J. Teece, Profiting from Tecbnological Innovation: 
adequately addressed how particular IP laws differentially affect entrepreneurial firms relative to more established ones. ${ }^{11}$

In response to this noticeable gap in knowledge, the Berkeley Center for Law and Technology (BCLT) conducted a wide-scale survey in 2008 of hightechnology startup firms in the United States to determine how these companies use and are affected by the patent system. Part of our aim in conducting the survey was to identify those aspects of the patent system that substantially encourage or hinder entrepreneurial activity, particularly in highgrowth technology industries such as the Internet, computer software and hardware, medical device, and biotechnology fields.

We were also concerned with the paucity of data regarding the potential effects of pending patent reform measures on entrepreneurs and on the entrepreneurial process more generally. Patent reform is currently the subject of a vigorous national debate. ${ }^{12}$ Recent studies by the Federal Trade Commission $^{13}$ and the National Academy of Sciences ${ }^{14}$ made specific policy recommendations that inspired this debate. This led to the drafting and discussion of various legislative proposals in Congress, starting in 2005 and continuing through the current session. ${ }^{15}$ There has also been a renewed interest in patent law in the Supreme Court, with the Court deciding several high-profile cases over the last several years. ${ }^{16}$ Recently, the Court granted certiorari in the highly controversial case of Bilski v. Doll, which will address

Implications for Integration, Collaboration, Licensing and Public Policy, 15 RES. POL'Y 285 (1986) (discussing the benefits of "complementary assets").

11. See Ted Sichelman \& Stuart Graham, Patenting by Entrepreneurs: An Empirical Study, 16 MICH. TELECOMM. \& TECH. L. REV. (forthcoming 2010) (reviewing most of the existing literature on patenting and entrepreneurship).

12. See, e.g., Dan L. Burk \& Mark Lemley, Don't Tailor Make Patent Act: The Key to Accommodating Competing Interests Lies in the Courts, 31 NAT'L L.J. 18 (2009).

13. Federal trade Commission, to Promote innovation: The Proper BALANCE OF COMPETITION AND PATENT LAW AND POLICY 4-17 (2003), available at http://www.ftc.gov/opa/2003/10/cpreport.htm.

14. COMm. ON INTEllectual Prop. RightS in the KNOWLEdge-Based ECON., NAT'L Research COUNCIL OF THE NAT'L ACADS., A PATENT SySTEM FOR THE 21ST CENTURY 81-130 (Stephen A. Merrill, Richard C. Levin \& Mark B. Myers eds., 2004), available at http://www.nap.edu/catalog.php?record_id=10976.

15. See generally Kevin R. Davidson, Retooling Patents: Current Problems, Proposed Solutions, and Economic Implications for Patent Reform, 8 HOUS. BUS. \& TAX L.J. 425 (2008) (describing various congressional bills); Carl E. Gulbrandsen et al., Patent Reform Should Not Leave Innovation Behind, 8 J. MARSHALL REV. INTELL. PROP. L. 328 (2009) (same as above).

16. See, e.g., MedImmune, Inc., v. Genentech, Inc., 549 U.S. 118 (2007); KSR Int'l Co. v. Teleflex Inc., 550 U.S. 398 (2007); eBay Inc. v. MercExchange, L.L.C., 547 U.S. 388 (2006). 
the scope of patentable subject matter for business methods. ${ }^{17}$ Bilski may also have implications for the patentability of software, a subject matter, along with business methods, of critical concern to many technology startups. Also of note, the U.S. Patent and Trademark Office (USPTO) has recently considered dramatic changes in the way patent applications are handled. ${ }^{18}$ The opinions of large corporations and the organized patent bar have been expressed very clearly in the judicial, legislative, and Patent Office reform debates, ${ }^{19}$ but input on how the proposed changes to patent law and policy will specifically affect entrepreneurship has been lacking. ${ }^{20}$

In the detailed results presented below, we do not offer simple answers to the difficult unanswered questions about the patent-entrepreneurship relationship. As one important example illustrates: although we find that holding patents is more widespread among technology startups than previously believed, company executives report that patents provide relatively weak incentives for core activities in the innovation process, such as invention and commercialization. These results raise the question: why would startups incur the substantial costs of patenting if they find patents are not

17. In re Bilski, 545 F.3d 943 (Fed. Cir. 2008), cert. granted sub nom. Bilski v. Doll, $129 \mathrm{~S}$. Ct. 2735 (2009).

18. See, e.g., Tafas v. Doll, 559 F.3d 1345 (Fed. Cir.), reh'g en banc granted, 328 Fed. App'x 658 (2009) (finding that the proposed continuation rules were inconsistent with the Patent Act); James W. Beard, Weeds in the Docket: Patent Continuation Reforms and Their Impact on Patent Applications in the Biotechnology Industry, $90 \mathrm{~J}$. PAT. \& TRADEMARK OFF. SOC'Y 423 (2008) (describing the PTO's proposed changes to the continuation rules). The USPTO recently withdrew its proposed changes, essentially mooting the case. See Susan Decker, U.S. Patent Office Drops Rules That Led to Glaxo Suit, BLOOMBERG, Oct. 8, 2009, http://www.bloomberg.com/apps/news?pid=newsarchive\&sid=alKiD9D4dOgc.

19. See, e.g., Brief Amicus Curiae of the Federal Circuit Bar Ass'n in Support of Respondents, Teleflex, Inc., KSR Int'l Co. v. Teleflex Inc., 550 U.S. 398 (2007) (No. 041350), 2006 WL 2983161; Amicus Brief for Pharmaceutical Research \& Manufacturers of America, MedImmune, Inc., v. Genentech, Inc., 459 U.S. 118 (2007) (No. 05-608), 2006 WL 2091231; Brief for Amicus Curiae Computer \& Communications Industry Ass'n in Support of Petitioners, eBay, Inc. v. MercExchange, L.L.C., 547 U.S. 388 (2006) (No. 05-130), 2005 WL 2381066; Kevin Bogardus, Stakeholders Inch Toward Final Deal on Patent Reform, but Rifts Remain, THE HILL, Feb. 13, 2008, available at http://thehill.com/business-a-lobbying/3467stakeholders-inch-toward-final-deal-on-patent-reform-but-rifts-remain.

20. See, e.g., Joe Mullin, Small Companies Suffering in Surge of Infringement Suits, THE RECORDER, June 4, 2009, at 3 ("When the Senate began debating patent reform in March, there was plenty of testimony from patent experts, but nothing from small entrepreneurs."). Although independent inventors have been active in the patent reform debates, not all independent inventors are entrepreneurs. See, e.g., Rick Merritt, Inventors' Group to Address Patent Reform, EE TIMES, June 4, 2009, available at http://www.eetimes.com/news/ latest/showArticle.jhtml?articleID=217701966. As such, a unique "entrepreneurship voice" has likely been missing from the reform debates. 
offering particularly strong incentives to engage in invention and commercialization?

Our response to this question is nuanced and multi-faceted. Specifically, a large share of early-stage companies, especially in the software industry, avoid the patent system altogether. At the same time, we find that startups hold more patents and patent applications than prior commentators have reported. ${ }^{21}$ These differences appear to be primarily attributable to our survey method, which captured many patents and applications-including those acquired from founders and from other sources-that previous studies had missed.

A dominant theme in our findings is that the usefulness of patents to technology entrepreneurs is driven by industry characteristics. So while we find that patents help many startups compete in the market with their technology, this role tends to be much more pronounced among biotechnology and hardware companies (including both medical hardware, such as surgical devices, and IT hardware, such as computers and semiconductors). Conversely, patents are much less important as a means by which most software firms - the majority of which hold no patents-capture competitive advantage from their innovations. ${ }^{22}$

Our results also shed light upon startups' motivations for filing for patents and for choosing not to patent major innovations. When electing to patent, startup executives tend to be most influenced by a desire to prevent copying and, to a lesser extent, by reputational and financial motives, including successful exit (such as being acquired or going public). In an important showing, we demonstrate that patenting may play a previously underappreciated role in helping startups to secure investment from various sources of entrepreneurial capital, including not only angel and venture investors, but also "friends and family" and commercial banks. Also notable is our finding that the costs of prosecuting and enforcing patents are a substantial barrier to technology entrepreneurs attempting to access the patent system. But the explanation for startups choosing not to patent is also context-specific: biotechnology company executives are much more likely to cite concerns about information disclosure than those in other industries.

Our results also show subtlety in the ways that startups contend with patents in their operating environment and their executives' attitudes toward the patent system. While respondents told us that checking the patent literature is reasonably common while innovating, startups at times do so

21. See infra Section III.B.2.

22. See id. 
only after launching their products or when considering patenting themselves. Licensing of others' patents is also not infrequent, and while startups are generally receiving information or know-how in the transaction, they are also commonly trying to settle a controversy-and in some cases they take patent licenses solely to avoid a lawsuit. On the whole, technology entrepreneurs tell us that the patent system is neither working particularly poorly nor well for their companies and industries.

Because many of these reasons for-and attitudes toward-patenting have little to do with the classical incentives and free rider stories, they are exemplary of many of the results we present in this Article. We find varied and subtle explanations for why technology entrepreneurs use the patent system: from the reasons they decide (or not) to file for patents on their innovations, to whether and when they examine the patent literature, to their views about the patent system as a whole. With this context in mind, Part I describes the specific research questions that motivated the survey, how the samples were selected, and some key profile characteristics of our respondents. Part II discusses the patent holding characteristics of technology startups, and the reportedly weak incentives patents provide to startups to engage in innovative activity. Part III offers our first set of findings that help explain why startups file for patents when they appear to offer relatively weak incentives to innovate. Part IV assesses the varied roles played by patents in helping the startup to compete, especially compared with other means available to the firm for capturing value from innovation. Part $V$ provides another set of key findings - those uncovering the motivations that entrepreneurs report for filing patents on their innovations. Part VI complements that discussion by exploring the reasons why technology entrepreneurs forgo patenting. Part VII completes the analysis by examining how technology entrepreneurs respond when they face patents held by others in their competitive environment. Part VIII explores our key attitudinal question in the survey, and reports on the general opinion among high-technology executives that the patent system is neither working particularly well nor particularly poorly for their companies and industries. Part IX offers some concluding observations about the scope of the study, the implications of our findings, and continuing our research in this area. 


\section{APPROACH TO SURVEYING HIGH TECHNOLOGY ENTREPRENEURS ABOUT THEIR USE OF IP}

We began our project with a set of research questions addressing a variety of topics concerning patenting and technology entrepreneurship, including the following: ${ }^{23}$

- Do startups apply for patents to protect their innovations and is this a successful strategy?

- Do they apply for patents for other reasons, e.g., to attract investors or for cross-licensing to obtain the right to use another company's patents?

- What role do actual or potential patent rights play in decisions to invest in startups?

- In what circumstances is strong patent protection a prerequisite to investment?

- In what circumstances are patent rights less important than other factors?

- How do investors and entrepreneurs assess the scope and value of their own and other firms' patent rights in the course of deciding which business opportunities to pursue or to fund?

- Once entrepreneurs have initial funding, are patent rights more important to the entrepreneur than to more established companies, which can rely on manufacturing, distribution and marketing capacities, brands and other reputation qualities, and their existing customer base to protect their market position?

- What steps do startups take to avoid infringing other parties' patent rights? Are they able to acquire licenses to such rights when necessary? Is inadvertent infringement a problem?

- How often do startups receive allegations of infringement and what do they do in response?

- Are entrepreneurs affected by "patent trolls" (that is, owners of patents who pursue patent litigation as a business model)?

23. We were aided in formulating our research design by insights and helpful comments during discussions with Hank Barry, John Barton, James Bessen, Tom Ciotti, Wes Cohen, John Duffy, Rebecca Eisenberg, Brad Feld, Richard Gilbert, Michael Goldberg, Josh Green, Bob Gunderson, Bronwyn Hall, Mitchell Kapor, Peter Menell, James Pooley, Walter Powell, Arti Rai, AnnaLee Saxenian, Carl Shapiro, Robert Strom, Lee Van Pelt, and David Yoffie, whom we thank. 
- How would patent reform proposals affect entrepreneurial companies?

Given the breadth of these research questions, we chose a research design that would allow us to provide meaningful empirical data on these issues. While some useful data is available in archival sources, much of the most useful information about how well or poorly the patent system is working for entrepreneurs resides with those who are starting and managing startup and early-stage companies. We therefore designed a survey questionnaire targeted to these issues and administered it to a large sample of technology entrepreneurs in companies across the United States.

In order to transform our research questions into a survey, we undertook extensive research and conducted numerous interviews with experts in the field and with active entrepreneurs. During this process we examined the theoretical and empirical literature in law, economics, management, and other social sciences to develop a series of hypotheses. ${ }^{24} \mathrm{We}$ also drew heavily from prior innovation surveys. ${ }^{25}$ Furthermore, our research team held discussions with scholars, university technology-transfer officers, independent inventors, startup founders and executives of early-stage companies, Silicon Valley lawyers, managers of venture capital (VC) firms, and angel investors in order to better understand the entrepreneurial environment and to craft questions

24. Some of the ideas covered by our questions were drawn from a number of sources. See Janice J. Jackson, The Usefulness of the General Social Surveys Database in Entrepreneurship and Small Business Research, in 4 ADVANCES IN ENTREPRENEURSHIP, FIRM EMERGENCE, AND Growth: DATABASES FOR THE STUDY OF ENTREPRENEURSHIP 393 (Jerome A. Katz ed., 2000); Jerome A. Katz, The Logic and Opportunities of Secondary Analysis in Entrepreneurship Research, in 4 ADVANCES IN ENTREPRENEURSHIP, FIRM EMERGENCE, AND GROWTH: DATABASES FOR THE STUDY OF ENTREPRENEURSHIP 5 (Jerome A. Katz ed., 2000); Richard C. Levin et al., Appropriating the Returns from Industrial Research and Development, 18 BROOKINGS Papers on Econ. ACTIVITY (SPectal IsSue) 783 (1987); Edwin Mansfield, Patents and Innovation: An Empirical Study, 32 MGMT. SCI. 173 (1986); Edwin Mansfield, Mark Schwartz \& Samuel Wagner, Imitation Costs and Patents: An Empirical Study, 91 ECON. J. 907 (1981); Jerry G. Thursby \& Marie C. Thursby, Who Is Selling the Ivory Tower? Sources of Growth in University Licensing, 48 MGMT. SCI. 90 (2002); Wesley M. Cohen, Richard R. Nelson \& John P. Walsh, Protecting Their Intellectual Assets: Appropriability Conditions and Why U.S. Manufacturing Firms Patent (Or Not) (Nat'l Bureau of Econ. Research, Working Paper No. 7552, 2000), available at http://ssrn.com/abstract $=214952$.

25. Multiple surveys were examined. See AM. INTEllectual Prop. LAw Ass'N, AIPLA 2005 ECONomic Survey (2005); CARnegie MEllon Univ. \& Alfred P. SloAn Found., ReSEARCH AND DEVELOPMENT IN THE UNited STATES (1994); GA. INST. OF TECH., INVENTORS AND THEIR INVENTIONS: UNDERSTANDING THE INNOVATION PROCESS (2007), available at http://www.prism.gatech.edu/ jwalsh6/inventors/Inventor Questionnaire.pdf; NAT'L SCI. FOUND., THE MANUFACTURERS' INNOVATION SURVEY (1993); Purdue Univ., Purdue Licensing Survey (1998). 
that would shed light upon topics that were not well understood, or for which there were conflicting explanations. ${ }^{26}$

\section{A. OUR Focus Is ON TECHNOLOGY STARTUPS}

\section{Targeting "Entrepreneurial Companies" and Their Top Executives}

The economist Daniel Spulber has critiqued the relative underrepresentation of the entrepreneur in neoclassical economic theory. ${ }^{27}$ In his view, entrepreneurship does not begin until the individual forms a startup firm, after which the individual and the enterprise are inexorably intertwined ${ }^{28}$ Spulber writes:

Entrepreneurs play a central role in the economy because they are the prime movers-the makers of firms....

... [Spulber's definition of the general theory of the firm places the entrepreneur at the center of microeconomic analysis. The entrepreneur engages in transactions that are needed to establish firms. In turn, firms create and operate markets and organizations. ${ }^{29}$

According to this theory, the period of entrepreneurship does not end until a true separation of ownership and control occurs. ${ }^{30}$

We approached the problem of surveying entrepreneurship in a manner consistent with that suggested by Spulber. While there are many pathways to better understanding the roles played by patenting in entrepreneurship, we

26. We had fruitful discussions concerning our questionnaire design with Hank Barry (Hummer Winblad Venture Partners), James Bessen (Boston University School of Law), Tom Ciotti (Morrison \& Foerster LLP), Wes Cohen (Fuqua School of Business, Duke University), John Duffy (The George Washington University Law School), Brad Feld (Foundry Group), Rich Gilbert (UC Berkeley Department of Economics), Bob Glushko (UC Berkeley School of Information), Christoph Grimpe (Centre for European Economic Research), Dominique Guellec (Organisation for Economic Co-operation and Development), Bob Gunderson (Gunderson Dettmer Stough Villeneuve Franklin \& Hachigian, LLP), Bronwyn Hall (UC Berkeley Department of Economics), Dietmar Harhoff (Ludwig-Maximilians University School of Business), Bob Lee (UC Berkeley Survey Research Center), Mark Myers (The Wharton School, University of Pennsylvania), Sean O'Connor (University of Washington School of Law), Lee Van Pelt (Van Pelt, Yi \& James, LLP), and John Walsh (Georgia Institute of Technology School of Public Policy), whom we thank for their insights.

27. See Daniel F. Spulber, The Theory of the Firm: Microeconomics with ENDOGENOUS ENTREPRENEURS, FIRMS, MARKETS, AND ORGANIZATIONS 156-57 (2009).

28. Id. at 151 .

29. Id.

30. Id. at 152. The separation of ownership and control has been a cornerstone of the economic theory of the firm for decades. See also ADOLF A. BERLE, JR. \& GARDINER C. MEANS, THE MODERN CORPORATION AND PRIVATE PROPERTY 69 (1933). 
elected to survey "entrepreneurial companies"- defined by us as companies founded in the United States during the last ten years. ${ }^{31}$ Given our research questions stated above, we were particularly keen to uncover the realities of patenting and entrepreneurship, rather than the intentions or attitudes of entrepreneurs. Noting the almost complete lack of empirical data on what entrepreneurs actually do when faced with decisions about intellectual property, we focused not on the intentions of would-be entrepreneurs, but rather on the choices that entrepreneurs in firms actually made while innovating.

Such a research design fosters the ability to provide meaningful insights about the role that IP rights play in a wide class of entrepreneurial activities. For instance, focusing on the company allowed us to inquire into the entity's age, employment, and share of scientists and engineers, and then relate these aspects to the company's patenting choices. Moreover, this research design permitted us to ask about the sources and success in garnering external funding, and relate these responses to the usefulness and utility of seeking patents. Critically, unlike the few European studies of small firm patenting, ${ }^{32}$ we avoided focusing solely on existing patent holders and, instead surveyed the broad class of entrepreneurial companies in order to offer insights into how the patent system is working for patentees and non-patentees alike.

Entrepreneurs generally become high-level executives of the firms they found and tend to be generalists who handle numerous aspects of their business. ${ }^{33}$ Aware that many firms have more than one founder, ${ }^{34}$ and driven

31. Entrepreneurs can run the panoply from "idea havers" to inventors to company founders. See generally David G. Blanchflower \& Andrew J. Oswald, What Makes an Entrepreneur?, 16 J. LAB. ECON. 26 (1998) (outlining characteristics of individual entrepreneurs); James W. Carland et al., Who Is an Entrepreneur? Is a Question Worth Asking, in 2 ENTREPRENEURSHIP: CRITICAL PERSPECTIVES ON Business AND MANAGEMENT 178 (Norris F. Krueger ed., 2002) (same as above); William B. Gartner, "Who Is an Entrepreneur?" Is the Wrong Question, 12 AM. J. SMALL Bus. 11 (1988) (same as above).

32. See Sichelman \& Graham, supra note 11, at 25-31 (reviewing these studies).

33. See Edward P. Lazear, Balanced Skills and Entrepreneurship, 94 AM. ECON. REV. (PAPERS \& PROC.) 208, 210 (2004) (noting that entrepreneurs are generalists who put together teams of people and assemble resources and capital, and to be effective, they must have a general set of skills).

34. See Chan Chaiyochlarb, If You Are Going to Launch a Startup, How Many Friends Would You Need?, TESTING TESTING 1,2,3, Feb. 23, 2007, http://blogs.msdn.com/testing123/ archive $/ 2007 / 02 / 23 /$ if-you-are-going-to-build-a-startup-how-many-friends-should-youstart-up-with.aspx (electing a non-scientific sample and arriving at a figure of 2.09 founders for successful firms); Brad Feld, How Many Founders Does a Startup Need?, FELD THOUGHTS, Feb. 25, 2007, http://www.feld.com/wp/archives/2007/02/how-many-founders-does-astartup-need.html (observing that startups tend to have two or three founders). 
by our interest in the innovation functions of the firm, ${ }^{35}$ we targeted our survey questionnaire to chief executive officers (CEOs), presidents, and chief technology officers (CTOs). Over three-quarters of our respondents identified themselves as being one of these three officers. ${ }^{36}$

\section{Selecting High Technology Sectors}

Because we were principally interested in knowing how patenting affects the technology entrepreneurship process, we limited our field of study to certain high technology sectors. Given the extensive writing, opinion, and theory about the differences in innovation and patenting characteristics between the life sciences and information technologies firms, we focused primarily on companies in the biotechnology and software industries. As such, much of our analysis below compares and contrasts the results of our survey in these two sectors. At the same time, we understood that other high-technology industries are important drivers of dynamism and growth. Accordingly, we also surveyed companies in the medical device and IT hardware sectors (the latter defined as semiconductor, communications, and computer hardware), and when meaningful and relevant, we report briefly here on their responses. While we are mindful that patenting may play an important role for startups in other industries, ${ }^{37}$ much of the patenting and venture-funding activity among small firms takes place in our chosen high technology sectors. ${ }^{38}$

35. We chose not to specifically target lawyers in the firm, on the theory that lawyers would tend to be comparatively more risk averse about divulging company information to outsiders.

36. This figure is actually an undercount, since some respondents who were presidents instead called themselves "Owner," and other officers neglected to identify themselves as "Chief Technology Officer" but instead as "VP of Engineering," "Chief Scientist," or the like. As such, our yield in these three categories was closer to $85 \%$. Among the "other" executives responding, they serve in many different functions, including those from operations (about $15 \%$ of all others), finance (about $10 \%$ of all others), and in-house lawyers (about $7 \%$ of the others), as well as marketing/sales and development (each about $5 \%$ of all others).

37. While the vast majority of our respondents fell into these four industry classifications, about $12 \%$ came from other sectors. Approximately $7 \%$ fell into medical technologies that did not include either "biotechnology" or "medical devices," and another $5 \%$ fell completely outside our technology definitions. For more information, see Stuart Graham \& Ted Sichelman, Patents and Innovating Startups: Analysis of the 2008 Berkeley Patent Survey (Nov. 24, 2009) (unpublished manuscript, on file with Social Science Research Network), available at http://ssrn.com/abstract $=1512726$.

38. See Robert E. Hall \& Susan E. Woodward, The Incentives to Start New Companies: Evidence from Venture Capital 3 (Nat'l Bureau of Econ. Research, Working Paper No. 13056, 2007), available at http://imio.haas.berkeley.edu/WilliamsonSeminar/hall021408.pdf. 


\section{Choosing Companies to Survey}

Because our research questions deal with how the patent system broadly affects technology entrepreneurship, we adapted our research design to two different types of entrepreneurial companies. First, we were interested in studying how patenting relates to the "average" entrepreneurial company. Second, we were keen to understand how the highest "quality" companiesnamely, those most likely to generate innovations, succeed, and grow-were using the patent system. We therefore chose two groups to survey: those representing the population of firms, and those that had been successful in securing VC funding. Unfortunately, there is no single association to which all high-technology entrepreneurial firms belong.

After examining the available data sources, we selected Dun \& Bradstreet (D\&B) as a proximate window into the overall population of companies in the United States. D\&B is a leading business credit-reporting and information source in the United States and holds over 140 million business records worldwide. ${ }^{39} \mathrm{D} \& \mathrm{~B}$ conducts entrance interviews to assign a credit rating to the companies in its database during which it determines technology class and founding date. We used D\&B's data on technology class ${ }^{40}$ and founding date to construct a sample of 10,500 D\&B-listed companies founded in our target industries after December 31, 1997. ${ }^{41}$

However, we also understand that venture-backed firms, though an important segment, make up only a small portion of the overall population of

39. The company reports that " 77 percent of D\&B's U.S. active file contains businesses with 10 or fewer employees." Dun \& Bradstreet, Facts \& Figures, http://www.dnb.com/us/about/db_database/dnbstatistics.html (last visited May 24, 2009). Based on a rough comparison with aggregate U.S. Census data, we estimated that D\&B contains about $60 \%$ of all companies founded in our target industries. See U.S. Census Bureau, Statistics of U.S. Businesses, http://www.census.gov/csd/susb/susbdyn.htm (last visited Sept. 23, 2009).

40. Using the entrance interviews, $D \& B$ assigns companies to Standard Industry Classifications (SICs), which we relied upon to select which companies fell into each industry sector. SIC numbers are not sufficiently differentiated to identify "biotechnology" companies - in the SIC codes, these companies are lumped together with other commercial researchers in SIC code 8731 "Commercial Physical and Biological Research" companies. We therefore relied upon D\&B's more fine-grained North American Industry Classification System (NAICS) coding to identify "biotechnology research" companies. The corresponding NAICS code is 541711. See U.S. Census Bureau, North American Industry Classification System, http://www.census.gov/eos/www/naics/ (last visited Sept. 23, 2009).

41. Our list included all D\&B's biotechnology companies (642) assigned to NAICS 541711 , all medical device companies $(1,048)$ assigned to SIC 3841 , and a random sample of its listed software companies $(8,810)$ assigned to SIC codes $7371,7372,7373$, and 7379. 
companies. ${ }^{42}$ Prior research shows that this small share of firms is disproportionately responsible for innovative output in the economy, ${ }^{43}$ and that venture capital funding is related to patenting activity. ${ }^{44}$ Because of our interest in understanding the role of patenting in startup investment, we chose to focus on this important class of companies by turning to the Thomson's VentureXpert data, which covers a substantial share of venturebacked companies in the United States. ${ }^{45}$ Using Thomson's rich data on company characteristics, we selected 5,600 companies primarily in our target sectors founded in 1998 or later that received venture or similar institutional

42. See Kortum \& Lerner, supra note 1, at 674 (noting that from 1983-1992, venturebacked firms' R\&D spending accounted for $3 \%$ of the U.S. total).

43. Id. at 675 (noting that while venture-backed firms account for just $3 \%$ of all $R \& D$ spending, they account for $8 \%$ of the innovative output and a disproportionate amount of patenting).

44. See David B. Audretsch, Werner Bönte \& Prashanth Mahagaonkar, Financial Signalling by Innovative Nascent Entrepreneurs (Ctr. for Econ. Policy Research, Discussion Paper No. DP7165, 2009), available at http://ssm.com/abstract=1345692; Iain M. Cockburn \& Megan MacGarvie, Patents, Thickets, and the Financing of Early-Stage Firms: Evidence from the Software Industry (Nat'l Bureau of Econ. Research, Working Paper No. W13644, 2007), available at http://ssrn.com/abstract=1037168; Carolin Haeussler, Dietmar Harhoff \& Elisabeth Müller, To Be Financed or Not . . . - The Role of Patents for Venture Capital Financing 2 (Munich Sch. of Mgmt., Discussion Paper No. 2009-02, 2009), available at http://www.ip.mpg.de/shared/data/pdf/haeussler_et_al_vcpat_jan20091mu_wp_reihe.pdf;

Paul H. Jensen, Elizabeth Webster \& Hielke Buddelmeyer, Innovation, Technological Conditions and New Firm Survival 5-6 (Melbourne Inst., Working Paper No. 26/06, 2006), available at http://ssrn.com/abstract $=946827$.

45. VentureXpert draws its data from portfolio companies funded by over 1,000 private equity partnerships, of which 700 are venture funds, and holds information on the funding transactions of over 4,350 VC firms derived from industry surveys as well as quarterly and annual fund reports. VentureXpert, About Us, http://vx.thomsonib.com/NASApp/ VxComponent/VXMain.jsp (last visited Oct. 1, 2009). But of. Steven N. Kaplan, Berk A. Sensoy \& Per Strömberg, How Well Do Venture Capital Databases Reflect Actual Investments? 1 (Sept. 2002) (unpublished manuscript, on file with the Chicago Graduate School of Business), available at http://ssm.com/abstract $=939073$ (suggesting that $V$ entureXpert tends to be biased toward California companies, and that most of the data come from the investors, not from the companies themselves). 
funding. ${ }^{46}$ Combining our $\mathrm{D} \& \mathrm{~B}$ and VentureXpert samples, our final list of target firms contained over 15,000 unique entities. ${ }^{47}$

\section{B. PROFILING OUR RESPONDENT COMPANIES}

In trying to profile the respondents in our survey, we are met with a difficult task. Since we purposefully set about to target entrepreneurial companies across a variety of characteristics (such as industry and age), there is no meaningful "average" respondent company. However, it is important to disclose the numerical breakdown of the responding companies' characteristics. We therefore offer descriptive statistics on the characteristics of the companies that answered our questionnaire, followed by statistics on the response rates to our survey.

Our median respondent (at the 50th percentile per category) is a selfdescribed "startup" company founded in April 2002. It has nine employees, half of whom are scientists or engineers, and has neither had an initial public offering (IPO) nor been acquired. ${ }^{48}$ The company's 2007 revenues were $\$ 300,000$, and its founders had prior experience running another company. Geographically, the company's offices are located somewhere west of the Mississippi River. In terms of funding its operations, the median respondent from our D\&B sample has received funding from "friends and family," at

46. Selection was made primarily on technology attributes. Thomson uses a proprietary industry classification that includes "Information Technology," "Medical/Health/Life Science," and "Non-High Technology." As of May 2008, of the over 11,000 U.S. companies founded after 1997 in their database, about 65\% were classed "Information Technology" and about $20 \%$ were assigned to "Medical/Health/Life Science." All companies with at least one email address for a company executive were included in our sample (3,359 companies), supplemented with a random sample of all remaining companies meeting our technology definitions.

47. We also administered our questionnaire to a group of companies in the "cleantech" (i.e., environmental technologies) market in conjunction with GreenTech Media, an online cleantech industry clearinghouse. Because we have a strong reason to believe that this sample was not representative of the population of cleantech startup firms, we do not report these results here. However, we plan to make these effectively anecdotal reports available.

48. In this regard, over $10 \%$ our respondents had been acquired or had undergone an IPO. So while our sample may have excluded some firms that effectively dissolved upon a successful exit, presumably D\&B and VentureXpert data did not exclude many of these firms. Furthermore, our sample also included many firms that had unsuccessfully dissolved, although we did not pursue extra efforts to locate former executives and founders of those firms. While in many, if not most of the circumstances, these executives were not reachable, there are responses in our data from companies that were winding down when the surveys were completed. Nevertheless, our respondent set generally excludes non-surviving firms. However, our bias testing of respondent versus non-respondent firm-level characteristics, described further infra, included both survivors and non-survivors in the latter category. 
least one "angel" investor, and a commercial bank, but not from venture capital firms, investment banks, or other companies.

Excluding our pre-test responses, 1,332 unique companies responded to our survey. Overall, this figure produces an $8.7 \%$ response rate. This uncorrected response rate does not account for companies that could not be reached, either because the contact information we had was inaccurate, or because the firm had gone out of business or fundamentally reorganized. We revised this base response rate by first correcting for returned mail (evidence of inaccurate physical address), ${ }^{49}$ and second by reference to the results of random sample telephone calls we conducted during the fall of $2008 .^{50}$

For the D\&B sample, we achieved a $7.0 \%$ response rate, and after correcting for bad addresses that figure becomes $8.4 \%$. Correcting further for telephone failures, the rate rises to $10.6 \%$. In the VentureXpert sample, we achieved a $12.4 \%$ response rate among companies for which we had emails. ${ }^{51}$ After accounting for mailing and telephone failures, the corrected response rate is $17.9 \%$.

In addition to higher response rates from VentureXpert companies, responses from medical firms were substantially more likely than from IT companies. $^{52}$ In the $\mathrm{D} \& \mathrm{~B}$ sample, the (telephone and mail-corrected) response rate for biotechnology and medical device firms is $23.7 \%$ and $13.4 \%$, respectively. For software and Internet companies, that same figure is 8.9\%. Among the VentureXpert sample, the (fully corrected) response rates for medical (biotechnology and medical device) and IT (hardware and software) companies are $24.2 \%$ and $15.6 \%$, respectively. ${ }^{53}$

Overall, we find that our respondents are not statistically different from the non-respondents on key company characteristics. Within industries, we

49. The U.S. Postal Service (USPS) returned approximately $17 \%$ of our mailings with "return to sender," "unable to forward," and "no longer at address" stamps. It is likely that this figure is low since the USPS returns less than $100 \%$ of non-deliverable mail, particularly when that mail, like ours, is not a first-class mailing.

50 . We found on average that $23 \%$ of the companies could not be reached at the telephone numbers provided by our data sources, though this figure was substantially higher in some sectors (e.g., $41 \%$ for venture-backed biotechnology firms).

51. We had an email address for at least one officer in $68 \%$ of the VentureXpert companies. Our testing shows that there are generally no significant differences in the way that the emailed and non-emailed (mail only) VentureXpert companies answered our survey. See Graham \& Sichelman, supra note 37.

52. In this regard, because of the reported importance of patenting to biotechnology companies, we took extra efforts to contact this group, telephoning every non-respondent, typically multiple times.

53. Based on our telephone calls, we found that approximately $23 \%$ of IT companies and $35 \%$ of biotechnology companies were not reachable at the telephone number provided by our data sources. 
find generally no statistically significant differences in the age, sales volume, or employee counts between respondents and non-respondents. ${ }^{54} \mathrm{We}$ also recognized the possibility that more active patentees may have chosen to disproportionately respond to our "patent" survey, so we matched our respondent and non-respondent companies to the USPTO patent record. Again, we find no statistically significant differences between the two groups in terms of the number of patents held by the companies, nor the number of applications filed since $2001 .{ }^{55}$ We have built statistical models based on firm characteristics to predict responses from non-respondents, and have also compared responses from our original pool of respondents to those garnered from a random telephone sample of initial non-respondents. While we do see a western bias in the companies responding to our survey, our testing generally shows that our respondents are not dissimilar in other important respects from our non-respondents. ${ }^{56}$ In sum, by and large, we can detect no statistical differences in the answers from the companies we were able to reach and the companies that declined to answer our survey. ${ }^{57}$

One of the main findings of our survey is that venture-backed companies are significantly different in the way they view the innovation, technology competition, and patenting processes. As such, we often report their responses separately in this Article. When these differences are not important, we combine the results.

54. $\mathrm{D} \& \mathrm{~B}$ software respondents are approximately one-half year younger than nonrespondents when we measure on the year (not date) of founding (significant at the $95 \%$ confidence level). Responding D\&B medical device companies have more employees than non-respondents (38 versus 14, a result which is weakly significant at the $90 \%$ confidence level). When we report confidence levels herein, we describe differences as either at $90 \%$, $95 \%$, or $99 \%$ level, but an actual confidence level may be higher than the reported value.

55. We can only see published applications after 2001 in the United States. We also tested for the number of patents (and applications) per year of age of the company, and again found no significant differences. See Graham \& Sichelman, supra note 37.

56. See id. The one exception is in the medical device sectors, in which respondents do appear to be different from the non-respondents in some respects. For instance, D\&B nonrespondents tend to have significantly more employees at the mean than the $D \& B$ respondents in this sector, although this difference is largely driven by a few relatively large outliers (i.e., larger firms, represented in this sector did not choose to respond to our survey). This finding may account for the large (yet insignificant) differences in non-respondents' patents and applications we found when matching to the USPTO data. Venture-backed companies in medical devices also show differences, with the non-respondents being significantly more likely to be founded earlier than respondents, which may again explain differences we see (albeit non-significant ones) in the larger number of patents granted to non-respondents in our USPTO name matching. See id. As such, we tend to downplay the reporting on these respondents in this Article.

57. For interested readers, we describe this bias testing in a separate article. See id. 


\section{PATENT (AND APPLICATION) HOLDING IN TECHNOLOGY STARTUPS}

\section{A. Patent Holding AmONG Startups Is Widespread BUt Not UBIQUITOUS}

\section{Startups' Patents Come from Several Different Sources}

Because we asked respondents to report the numbers and origins of the patents and applications they held, our survey results offer a uniquely accurate window into the patenting behavior of early-stage technology companies. In the past, scholars have tried to match granted patents listed in the USPTO database to company names by using data in the assignee field. ${ }^{58}$ This method tends to produce an undercount because it misses patents that were assigned to the company from the founders post-grant or otherwise acquired from outside the firm. ${ }^{59}$ While scholars have generally not used the USPTO reassignment data to supplement the original assignments, even in this regard the USPTO records on patents reassigned to different entities after grant are notoriously incomplete. ${ }^{60}$ Further compounding the difficulty

58. See, e.g., Bronwyn H. Hall, Adam Jaffe \& Manuel Trajtenberg, Market Value and Patent Citations, 36 RAND J. ECON. 16, 20 (2005).

59. Although published patent applications have recently become available in the United States, they too cannot be relied upon to give accurate results. First, they have only been published since 2001. Second, they are only published after eighteen months, which means that the most recent applications cannot be counted. Third, there is a class of patent applications that do not require publication. Applicants can disclose to the Patent Office that they do not intend to seek patent protection in any other jurisdiction with an eighteen month publication rule and opt out of the requirement. See 35 U.S.C. $\$ 122(\mathrm{~b})(2)$ (B) (2006). Estimates vary, but it is believed that between $5-15 \%$ of applications take advantage of this statute. See Stuart J. Graham, Continuation, Complementarity, and Capturing Value: Three Studies Exploring Firms' Complementary Uses of Appropriability Mechanisms in Technological Innovation 36 (Spring 2004) (unpublished Ph.D. dissertation, UC Berkeley) (on file with the UC Berkeley Library). Additionally, small firms are among the most likely to elect non-publication, since they are comparatively less likely to market their products outside the United States. See Mark D. Janis, Patent Abolitionism, 17 BERKELEY TECH. L.J. 899,919 (2002).

60. Although the Patent Office offers a recording system, it is merely optional, and the recording of assignments appears to be routinely ignored. See 35 U.S.C. $\$ 261$ (2006). In essence, the law establishes a registration system with a notice statute protecting subsequent purchasers for value. See id.; U.S. PATENT \& TRADEMARK OfFice, MAnual of PATENT EXAMINING PROCEDURE $\ 301$ (8th ed., rev. 7, 2008). The registration system is organized in a fashion analogous to a "land deed" registry, in which the person or entity that purchases later without notice of an earlier transfer prevails over the earlier transferee, if it did not record within a grace period. See 35 U.S.C. $\$ 261$ (2006); U.S. PATENT \& TRADEMARK Office, Manual of Patent Examining Procedure $\$ 301$ (8th ed., rev. 7, 2008). Because the market for buying and selling patents is presumably subject to extensive due diligence and other forms of contracting that prevent fraudulent assignments of patents, 
of knowing "what patents companies have" is the problem of namematching, which stems from the multiple forms of company names, corporate name changes, and typographical errors in the patent records themselves. ${ }^{61}$ Moreover, arriving at accurate counts may be particularly difficult for early-stage companies since-as our survey results show-it is common for startups' patents to originate with founders prior to the company's founding date. Such patents may first issue to founders (as individuals, with no initial corporate assignee) and only later be assigned to the company. Because startups are resource constrained (in money and time), it may be less likely that these companies update their assignment records at the Patent Office. ${ }^{62}$ Effectively tracking these patents would require knowing the names of the founders and matching them to the USPTO patent inventor records. And with common names, that second task can be a herculean labor. ${ }^{63}$

Our survey results are not prone to these difficulties, and thus offer superior information about the patent holdings of early-stage technology companies. Instead of relying on matching, we asked our respondents to report to us the number of U.S. patents or filed applications held by the company from three unique sources: (1) those coming from founders that were applied for prior to the company founding date; (2) those acquired by the company from sources other than its founders; and (3) those filed by the company itself after its founding date.

\section{Startups Hold Numerous Patents, but Explanations Are Nuanced}

Because studies relying on the USPTO database had reported average patent holdings for venture-backed startup companies in the range of 0.5-6.0 patents ${ }^{64}$ we were surprised to find that, on average, the companies in the population of high-tech firms (as proxied by D\&B) hold well over four (4.7)

arguably there is not as great a need to pay attorneys' and filing fees to record reassignments as with real property.

61. For instance, the assignee "Minnesota Mining and Manufacturing Company" also appears as assignee " 3 -M" in U.S. Patent No. 4,000,444 (filed Mar. 12, 1973).

62. See Dennis Crouch, Another University Patent Ounership Dispute: Stanford Loses Rights Based on Researcher's Side Agreement, PATENTLY-O, Oct. 1, 2009, http://www.patentlyo.com/ patent/2009/10/another-university-patent-ownership-dispute-stanford-loses-rights-basedon-researchers-side-agreement.html ("Patent ownership regularly transfers without the new owner recording the assignment with the USPTO.').

63. See Manuel Trajtenberg et al., The 'Names Game": Hamessing Inventors' Patent Data for Economic Researcb (Nat'l Bureau of Econ. Research, Working Paper No. W12479, 2006), available at http: $/ /$ ssrn.com/abstract $=926058$ (discussing the difficulty of the inventor namematching problem).

64. See Ronald J. Mann \& Thomas W. Sager, Patents, Venture Capital, and Software Startups, 36 RES. POL'Y 193, 197 (2007). 
patents and applications (Table 1). Among the venture-backed firms in our survey-a more comparable sample to previous studies- - the average firm holds just under nineteen patents and applications (18.7). These figures are somewhat misleading, though: among the $\mathrm{D} \& \mathrm{~B}$ respondents, over six in ten companies (61\%) hold no patents at all. Moreover, these average statistics are influenced by a few patent holders with very large portfolios. For instance, one of the respondents in our D\&B sample reports holding 260 patents and applications from all sources. Similarly, one venture-backed company holds 570 total patents and applications.

We observed earlier that there are important differences between the very select venture-backed startups and companies drawn from the larger population of companies (most of this latter set having no venture investment)-and this observation also applies to patent ownership. For instance, among those startups drawn from the D\&B sample (approximately $85 \%$ of which have no venture backing), the median company (the firm at the 50th percentile) holds no patents or applications. Venture-backed companies are substantially different from the $D \& B$ respondents: the median venture-backed firm holds six patents or applications. Among venturebacked firms, a comparatively small $18 \%$ hold no patents or applications, about one-third the share exhibited by the D\&B companies.

These findings suggest that the holding of patents by technology startups is more widespread than previously believed, especially among venturebacked companies, but that holding patents is by no means ubiquitous among entrepreneurial firms. Substantial numbers of early-stage technology companies appear to be opting out of the patent system altogether, and these firms are not merely clustered among the younger companies. In fact, the likelihood of not holding any patents is virtually the same among the youngest and oldest companies in our study. For example, among the older D\&B companies in our sample (those founded prior to 2003), $64 \%$ of firms report holding no patents. ${ }^{65}$ Therefore, the likelihood of holding (or not holding) patents by technology startups does not appear to be driven by age effects, but instead by the company's business model, strategy, technology, or other factors, such as the cost of patenting and subsequent enforcement. ${ }^{66}$

65. We note that there is not a hidden "technology" effect to these findings: the share of companies that are identified as biotechnology, medical devices, or software are virtually identical among the older and younger companies.

66. Among those firms that chose to hold patents, however, there is a positive influence of age on the number of patents held. See Graham \& Sichelman, supra note 37. 
Table 1: Patents and Applications Held by Startup Companies ${ }^{67}$

\begin{tabular}{|c|c|c|c|c|c|}
\hline $\begin{array}{l}\vec{E} \\
\stackrel{0}{0} \\
\underline{E} \\
E\end{array}$ & 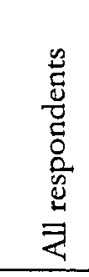 & 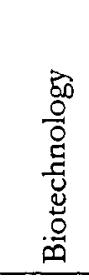 & 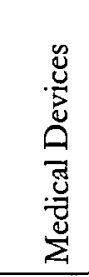 & 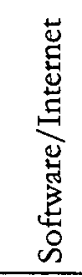 & 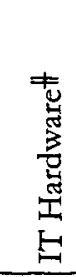 \\
\hline \multicolumn{6}{|l|}{ Population of companies (D\&B) } \\
\hline Companies holding patents/applications (share) & $39 \%$ & $75 \%$ & $76 \%$ & $24 \%$ & - \\
\hline Average \# patents/applications held (all companies) & 4.7 & 9.7 & 15.0 & 1.7 & - \\
\hline Average \# filed by company (patent holders only) & 8.1 & 8.5 & 13.0 & 5.0 & 一 \\
\hline Average \# from founders (patent holders only) & 1.9 & 2.0 & 3.0 & 1.2 & - \\
\hline Average \# acquired (patent holders only) & 2.1 & 2.4 & 3.7 & 0.9 & - \\
\hline \multicolumn{6}{|l|}{ Venture-backed companies } \\
\hline Companies holding patents/applications (share) & $82 \%$ & $97 \%$ & $94 \%$ & $67 \%$ & $91 \%$ \\
\hline Average \# patents/applications held (all companies) & 18.7 & 34.6 & 25.2 & 5.9 & 27.4 \\
\hline Average \# filed by company (patent holders only) & 15.8 & 22.9 & 16.1 & 7.1 & 23.6 \\
\hline Average \# from founders (patent holders only) & 2.5 & 3.8 & 3.8 & 0.7 & 3.1 \\
\hline Average \# acquired (patent holders only) & 4.2 & 9.0 & 6.5 & 0.7 & 3.5 \\
\hline
\end{tabular}

\# Available only for VentureXpert listed companies.

\section{Technology Entrepreneurs Suggest the Patenting Story Is Complex}

To better understand the underlying rationale of our respondents' answers, we conducted several hour-long, follow-up interviews by telephone in the early months of $2009 .{ }^{68}$ The comments of one such executive, call him Neil, are illustrative of what is often a tension for the entrepreneur in deciding whether to seek patent protection. Neil is the inventor of an innovative biometrics information technology and CEO of a startup he founded in 2003 to commercialize the technology. While his company has

67. Results are based upon two questions from the survey. (1) "Does your company own U.S. patents or has it applied for U.S. patents (including any patents or applications acquired through any purchase or transfer)?" and (2) "How many, if any, U.S. patents or pending applications does your company have from the following sources: Patents or pending applications applied for by Founders prior to the company's founding date? Patents or pending applications purchased, transferred, or assigned to company? Patents or pending applications filed by your company since founding?"

68. Our interviews were conducted on a convenience sample of our respondents. We began with a random sample of respondents who had provided email addresses to us (approximately $80 \%$ of the total), and disproportionately contacted respondents in Northern California. We did, however, speak with all respondents who were willing to speak with us. 
filed one patent application that has not yet been granted, he has generally tried to avoid patents even though his investors, which include VC firms, are interested in him having them. He stated:

Our business is a consumer services business; it was never my intention to be a monopoly and to protect [this technology] .... Instead, our strategy is to grow as the number one supplier of [our new product] while simultaneously allowing other, smaller companies to spread [the underlying technology] around the nation. In doing so, [the technology] will have a huge consumer base and our company will be viewed as the prominent player, much like "Kleenex" is in the tissue industry.

Neil's comments help expose several themes that run through our survey responses. First, patenting is common among our respondents, but by no means ubiquitous. Second, patenting for the entrepreneurs choosing to hold patents is often motivated by reasons that have not commonly been wellunderstood or studied in the literature. And third, the incidence and usefulness of patents to technology entrepreneurs is very much determined by the industry and technology in which the company is operating.

B. In Patenting, Not All Startups Are Created Equal

\section{Industry Influences the Incidence of Startups Holding Patents}

Similar to the patenting differences associated with the presence of venture funding, we find profound disparities in the likelihood, number, and original source of patents by the technology focus and industry of the company. Among the D\&B sample, biotechnology and medical device companies are much more likely to hold patents and applications than are software and Internet firms (Table 1). In fact, three out of four of these medical companies report holding patents and applications compared with only one in four among software startups.

There are also substantial differences across industries in the number of patents held on average, with the total patents of medical and life science companies once again substantially greater than those of the software and Internet firms in the D\&B sample. Medical device companies report holding fifteen patents and applications on average, compared with just under ten for biotechnology research companies. These figures are significantly higher than for software companies, which hold on average less than two patents and applications. Much of this difference is driven by the relatively high likelihood of software firms holding no patents. If we compare the average

69. Interview with anonymous executive, March 2009 (emphasis in original). 
count of patents and applications held by firms that have chosen to hold patents, D\&B software and Internet firms compare more closely with $D \& B$ biotechnology research companies (7.1 patents to 12.9 patents, respectively). Additionally, large patent-portfolio companies influence the result: among those $\mathrm{D} \& \mathrm{~B}$ companies that hold patents, the median software startup (at the 50th percentile) holds two patents and applications and the median biotechnology firm possesses six. In the IT sector, hardware companies hold significantly more patents than their software counterparts: venture-backed IT hardware firms hold on average more than twenty-seven patents and applications, about five times more than similarly-funded software and Internet companies.

While there are substantial inter-industry differences at the level of the average $\mathrm{D} \& \mathrm{~B}$ company, focusing instead on those companies choosing to hold patents demonstrates smaller or insignificant differences as to the origin of the patents held by the firm. Across the D\&B patent holders, about two patents and applications come into the firm from its founders, and while this number falls to nearly one for the (fewer) software and Internet companies holding patents, the difference is not statistically meaningful. For every ten employees at a patent-holding $D \& B$ company, the firm files seven patents on average, and it acquires two patents or applications from sources other than its founders. These figures change little based on the technology of the company, and the differences are not statistically meaningful. In sum, for startup companies that hold patents, the likely origin of those patents remains virtually the same regardless of the technology focus of the firm. What is significantly different, though, is the likelihood of holding any patents-software and Internet companies in the population (as proxied by D\&B) are much less likely to hold patents than similar companies involved in the health-related technologies.

\section{Venture-Backed Companies Are More Likely to Hold Patents}

These inter-industry differences also persist among the venture-backed firms, where the incidence of holding patents is much higher and the origins of those patents are more varied. Table 1 shows that virtually all (97\%) companies in the biotechnology and medical device sectors hold patentsand while holding patents is less likely for venture-backed IT firms (hardware and software alike), the rates are still relatively high (about $90 \%$ and $70 \%$, 
respectively). Venture-backed firms are much more likely to hold patents, regardless of technology focus. ${ }^{70}$

In order to better understand the motivations for venture-backed companies to patent, we interviewed several partners at VC firms. One such partner holds an engineering degree, invests primarily in biotechnology companies, and has extensive experience in the technology, business, and investment environments in which his portfolio companies operate. $\mathrm{He}$ stated:

When you go into life sciences-and in reality, with any [biorelated technology] that you're creating or acquiring-if it doesn't have a reasonably strong patent, and if you don't have the capability to expand the patent estate covering your technology and products, you are going to have complicating issues. [As a young company], you need to secure patents, and with the broadest claims and specifications that you can get. ${ }^{71}$

These comments support two clear messages that spring from our responses. First, early-stage biotechnology companies are much more likely to use, and to see utility in using, the patent system. Second, venture investors are interested in patents, and venture-capital backed companies are much more likely to hold and file for patents. Whether this second observation is primarily driven by investors demanding a more active patent "footprint" of the companies they fund or by companies that VCs fund simply being more likely to supply patents to investors, we are unable to say with certainty. Our evidence points, however, to a relationship that runs both ways. Firms that seek venture-funding appear to be patenting more actively prior to the funding event (and for the purpose of securing funding), and venture-capital investors appear much less willing to fund companies that hold no patents.

In this sense, the results of our survey differ substantially from several prior studies of startup patenting. In particular, we show that among venturebacked companies, patent-holding is more widespread and-in conjunction with additional data we present below ${ }^{72}$-more important to securing venture investment than previously reported. The best prior evidence on the topic comes from Ronald Mann and Tom Sager, who matched venture-backed companies to the Delphion patent database. ${ }^{73}$ Their article reports that

70. The finding that venture-backed firms are substantially more likely to hold patents is consistent with an earlier study finding that venture-backing has a positive influence on patenting. See Kortum \& Lerner, supra note 1.

71. Interview with anonymous venture capital firm partner (May 2009).

72. See infra Parts IV, V.

73. Mann \& Sager, supra note 64, at 196. 
venture-backed software firms hold on average just under three patents, while venture-backed biotechnology companies possess just under 5.5 patents. ${ }^{74}$ Moreover, they state: " $[\mathrm{O}]$ nly $2 \%$ of software firms had more than 4 patents, and less than $1 \%$ of software firms had more than 10 patents; $19 \%$ of biotechnology firms had more than 4 patents and $6 \%$ had more than 10 patents." 75

Our responses from startup company executives show that patents are more widely held, and held in greater numbers, than Mann and Sager estimate. Our respondent venture-backed software and Internet firms hold on average just under six patents and applications, ${ }^{76}$ double the estimate of Mann and Sager, while venture-backed biotechnology companies hold just under thirty-five patents, more than six times what Mann and Sager estimate. If we restrict ourselves only to patents and applications filed by these firms (thus more closely approximating Mann and Sager's patent-matching-andcounting method), our venture-backed software respondents report filing 4.9 patents on average, while venture-backed biotechnology companies file 22.2 at the mean-still substantially higher than the figures estimated by Mann and Sager.

In contrast to Mann and Sager's suggestion that patent holding is reasonably uncommon, ${ }^{77}$ our respondents tell us that $63 \%$ of venture-backed software and Internet startups hold more than four patents and applications, while more than $47 \%$ of these firms reported holding more than ten. Extending this analysis to venture-backed biotechnology startups, we find that $86 \%$ of these companies report having more than four patents and applications while $60 \%$ hold more than ten. These discrepancies with the figures cited in Mann and Sager may be partly accounted for by the earlier time period of their study ${ }^{78}$ and the fact that not all applications result in an

74. Id. at 197.

75. Id. at 198.

76. We also find that venture-backed IT hardware firms hold on average more than twenty-seven patents and applications, about five times more than similarly-funded software and Internet companies.

77. Mann \& Sager, supra note 64, at 197-98.

78. Mann and Sager examined companies that received their first rounds of funding in 1996-1998, measuring patent grant rates as of the end of 2004. As such, the higher patenting numbers we see among firms in our data could reflect an increasing patenting trend over time in startups-though such a trend is arguably unlikely to account for a substantial share of the large differences reported here. Additionally, although it may appear that Mann and Sager's time window is shorter than ours, it is not. In particular, because most startups do not receive venture capital financing until more than one year after founding, Mann and Sager's effective time horizon appears to be about seven to ten years. An analysis by the authors shows that firms listed in VentureXpert that have issued patents (matched to the USPTO data) have, on average, initial VC funding arriving about 2.5 years after company 
issued patent. ${ }^{79}$ This latter possible explanation may be undercut, however, insofar as the grant rate of startups' patent applications is higher than usual because (a) the quality of the invention may be higher than average ${ }^{80}$ and (b) the patent applicants themselves may care more about winning a granted patent, and thus expend more time, effort, and money in the application process. ${ }^{81}$

Another noteworthy finding of our study is that founders bring substantial numbers of patents and applications with them into their startups. Another possible source for our differences with Mann and Sager's estimates is their failure to account for founder-added patents that go unrecorded at the USPTO. ${ }^{82}$ When a D\&B-listed biotechnology startup holds patents, its founders tend to bring on average two patents and applications into the firm, a figure that nearly doubles to 3.8 when the firm has venture backing. ${ }^{83}$ Venture-backed medical device and IT/hardware firms that hold patents tend to acquire more than three patents and applications on average from their founders. However, for patent-holding software companies with

founding. Although our study focused on firms founded after 1997, because many of those firms were not founded until much later (the median founding date for all firms was 2002), the effective windows appear roughly equal, if not shorter in our study.

79. There is conflicting evidence about the USPTO's application grant rate. See Robert A. Clarke, U.S. Continuity Law and Its Impact on the Comparative Patenting Rates of the US, Japan and the European Patent Office, 85 J. PAT. \& TRADEMARK OFF. SOC'Y 335 (2003) (responding to an earlier study by Quillen and Webster); Ron D. Katznelson, Bad Science in Search of "Bad" Patents, 17 FED. CIR. B.J. 1 (2008) (discussing problems involved in grant rate calculation); Cecil D. Quillen, Ogden H. Webster \& Richard Eichmann, Continuing Patent Applications and Performance of the U.S. Patent and Trademark Office - Extended, 12 FED. CIR. B.J. 35 (2002) (evaluating prior date to revisit determination of the USPTO grant rate); Mark A. Lemley \& Bhaven Sampat, Is the Patent Office a Rubber Stamp?, 58 EMORY L.J. 181, 184-89 (2008) (pointing to data controversies in calculating patent grant rates).

80. See Kortum \& Lerner, supra note 1, at 690 (finding that venture-backed firms' patents have significantly more forward citations than the population of patents). But of. Jean O. Lanjouw \& Mark Schankerman, Protecting Intellectual Property Rights: Are Small Firms Handicapped?, 47 J. L. \& ECON. 45 (2004) (finding that patent portfolio size is positively related to forward citations).

81. See infra notes 188-89 and accompanying text (finding that startups expend twice or more on out-of-pocket costs on patenting than previously-reported averages). See generally Stuart J.H. Graham \& Dietmar Harhoff, Separating Patent Wheat from Chaff: Would the U.S. Benefit from Adopting a Patent Post-Grant Review? (Oct. 14, 2009) (unpublished manuscript, on file with Social Science Research Network), available at http://papers.ssrn.com/ abstract_id=1489579 (suggesting higher grant rates among triadic patents demonstrate that extra effort pays off in winning patents).

82. See Mann \& Sager, supra note 64, at 196-97.

83. These differences are significant at the $95 \%$ confidence interval. 
venture funding, founders are likely to bring fewer than one patent or application with them into the startup. ${ }^{84}$

After founding, venture-backed biotechnology and medical device companies are also more likely than software and Internet firms to file patent applications and to acquire patents (or applications) from sources other than their founders. For these biotechnology and medical device firms that hold patents or applications, they report that on average eight originate from acquisitions (other than from founders), and that they directly file twenty applications. These figures are substantially higher than the just over 0.5 patents or applications acquired on average by venture-backed software and Internet firms, and the seven directly filed by these startups. Interestingly, IT hardware firms are the outlier: these companies are more like the healthrelated firms in terms of their number of founder-originating patents and patent filings, but are also similar to their software counterparts in that they tend to acquire comparatively few patents from sources other than founders.

\section{Patents May OfFer Only Mixed to Weak InCENTtVes to ENGAGE IN INNOVATION}

Given that the patent monopoly is most commonly justified on the ground of providing incentives to innovate, we were surprised to find that, in general, the technology startup executives responding to our survey report that patents offer relatively mixed to weak incentives to engage in innovation. In this context, we refer to the term "innovation" in its Schumpeterian sense-the series of steps taken from idea to invention to development to commercialization. ${ }^{85}$ To uncover patents' incentive value, our questionnaire asked all respondents how strong or weak an incentive $(1=$ not at all, $2=$ weak, $3=$ moderate, and $4=$ strong incentive) patents served for undertaking four innovation-related activities: (a) inventing new products, processes, or services; (b) conducting initial research and development; (c) creating internal tools or processes to build or implement final products, processes, or services; and (d) undertaking the risks and costs of making, selling, and marketing a commercial product. In general, the executives we surveyed reported that patents serve as only slight to moderate incentives for each of these stages in the innovation process.

84. It is noteworthy that among software firms, the average number of founderoriginating patents is lower for venture-backed companies ( 0.7 patents) than for those in the $D \& B$ population sample (1.2 patents), although this difference is not statistically significant at conventional levels.

85. See SCHUMPETER, supra note 1 , at 66 (contending that innovation consists of novel goods, production methods, markets, production inputs, and forms of organization). 
We recognized during the design stage of our survey instrument that the meaning of the term "incentive" could be interpreted in several ways by our respondents. While we cannot dismiss the possibility that our respondents may not have understood the term incentive in the way that neoclassical theory generally presents it, ${ }^{86}$ our preliminary testing and interviews suggested to us that the business-savvy technology entrepreneurs we surveyed do interpret that term in the way that theory presents it. Moreover, there is ample evidence that the patents-as-incentives rationale is a well-known concept in the mainstream business literature and media. ${ }^{87}$ Of course, while the respondents may have understood our questions, they may not fully comprehend the role patenting actually plays in their innovation process, which is often subtle. ${ }^{88}$ So while we are reasonably confident that our responses capture at least a proximate window into the incentive role that

86. See Jean Tirole, The Theory of Industrial Organization 390 (1988) (inducing innovation through an award of a temporary monopoly ultimately benefits the public good).

87. See, e.g., Robert J. Barro, Drugs Via Canada? The Side Effects Could Hurt, Bus. WK., Aug. 30, 2004, at 34 ("Pursuing these policies would be a mistake because the current setup strikes a reasonable balance between incentives for invention and the prices of existing drugs."); Hiawatha Bray, Ethernet Pioneer: Patent System Is Flawed, but Still the Best We've Got, BOSTON GlOBE, May 13, 2007, at D3 ("When you grant private property, you create an incentive to invest and protect and make the best use of that property. A patent, which is a form of private property, is itself a form of technology for encouraging innovation." (quoting Bob Metcalfe, partner, Polaris Venture Partners)); Michael Fitzgerald, $A$ Patent Is Worth Having, Right? Well, Maybe Not, N.Y. TIMES, July 15, 2007, at BU3 ("Patents are supposed to give inventors an incentive to create things that spur economic growth."); Gloria Lau, U.S. Policy on Prescription Drugs Keeps Raising Eyebrows, InVESTOR'S BUS. DAILY, July 25, 2005, at A7 ("There's got to be a worldwide push to honor intellectual property. Otherwise there's no incentive to do drug research."); Gary L. Reback, Patently Absurd, FORBES, July 21, 2002, at 44 ("But as an incentive to innovate, a patent holder gets a free pass from the rigors and challenges of competition. The right amount of such incentive may well spur invention.").

88. For instance, it may be that people think of "an incentive" as somehow the proximate cause or reason for conducting $R \& D$ and other innovation-related activities, in which case a respondent may not have connected the term "incentive" with more "secondary" incentive effects that patents may play in spurring the activity. In other words, people may well think: "I would have conducted this innovation anyway, even without a patent." Indeed, because one rarely knows the outcome of an $R \& D$ project, and never knows the complete shape of the prior art, very few inventions would be created if the certainty of patenting was required to begin $R \& D$. What people may not realize, however, is that the "secondary" effects of patents - such as attracting capital and enabling arm's-length transactions-may in the aggregate contribute enough of a "plus factor" to make certain projects viable, even if people do not think of patents in those terms. Thus, respondents may not have appreciated the idea of a "marginal incentive effect," thinking of incentives as more of an "all or nothing" concept. 
patents play for technology entrepreneurs, we nevertheless recognize that further investigation of our findings is warranted.

\section{The Reported Relatively Weak Incentive Value of Patents}

Among the $D \& B$ companies, respondents told us that on average, patents offer just above a "slight incentive" to engage in invention, $R \& D$, and commercialization, and between "slight" and "no incentive at all" to create internal tools and processes. While venture-backed startup executives rate the incentive value more highly than do those at $D \& B$ companies, in no category are patents reported to provide even a "moderate" incentive for any of the four entrepreneurial activities about which we queried.

An interview we conducted with the sole proprietor of a medical device company assisted us in understanding some of the low-powered incentives that patents offer. This physician-turned-entrepreneur-whom we will call Jeremy - has chosen largely to opt out of the patent system. As is the case with many innovations in medical devices, Jeremy was a "user-innovator," seeing a practical problem in his medical practice that needed a practical response. ${ }^{89} \mathrm{He}$ founded his company to offer a product to meet that need, and quickly secured a patent. This lone patent, however, has not allowed him to compete effectively, and he perceives very little incentive to seeking patent protection today:

Fifteen years ago, patents were probably very useful and offered a lot of protection. But not today. In fact, today they are not very valuable at all, and, even if I were to get a patent on my [updated technology], odds are that I would still find a copy for sale on the side of the road in China. ${ }^{90}$

Jeremy's comments highlight two aspects associated with the incentive value of patents expressed in our survey responses. First, respondents tell us in general that the incentive value provided by patents is typically low for a range of innovative activities. Second, the pattern of reporting relatively weak incentives generally holds not just for those companies that do not patent, but also among those companies that do.

To verify that those companies holding patents were also reporting relatively low incentives, we divided our respondents into two categories: companies that told us they held at least one patent or application and companies holding none. We show that, as we expected, companies

89. See generally ERIC VON HIPPEL, DEMOCRATIZING INNOVATION (2005) (describing "user innovation" as technology supplied by technology users who experience a need and innovate to fill that need).

90. Interview with anonymous company founder (Feb. 2009). 
expending resources to acquire patents rate their incentive value higher in all categories than do those companies holding none. However, the incentive value that these active patent holders ascribe to patents still does not, for any of the four innovative activities, reach on average even the "moderate incentive" level. And for those companies that report holding zero patents or applications, the incentive value of patents is ranked by respondents on average between "slight incentive" and "no incentive at all" for each of the four innovation activities.

An important caveat to these findings, however, is a marked interindustry difference in the incentive values that patents offer for innovation. For example, biotechnology companies report that patents generally provide "moderate" incentives in the innovation process, whereas software firms report that they generally provide at best "slight" incentives. This finding is consistent with inter-industry differences in the incidence and numbers of companies holding patents discussed above. ${ }^{91}$ While these incentive results are also consistent with anecdotes about software firms, ${ }^{92}$ we were somewhat surprised to find that, in the biotechnology sector, companies did not report a stronger connection between the incentives offered by patents and innovation. Interestingly, these incentive results do not substantially change when limiting the sample only to those firms that are actually holding patents.

Our findings on the incentive value of patents are noteworthy given the legal and theoretical bases for the "patents as incentives" view. The U.S. Constitution, the foundation for the intellectual property laws in the United States, provides for patents primarily upon the incentive view. ${ }^{93}$ And at least since Nobel Laureate Kenneth Arrow's 1962 work on the value of intellectual property in spurring research and development, economists have examined the value that society gains from offering patents (in the form of limited monopolies) to "idea havers" as an incentive to convert those ideas into inventions. ${ }^{94}$ Noting that patent rights generally live well beyond the creative spark of invention, ${ }^{95}$ other scholars have suggested that patents serve as incentives throughout the innovation process, across a range of

91. See supra Section III.A.

92. See Ronald J. Mann, Do Patents Facilitate Financing in the Software Industry?, 83 TEX. L. REV. 961, 1001 (2005).

93. $S_{e e}$ U.S. CONST. art. I, $₫ 8$, cl. 8 .

94. See Mansfield et al., supra note 24, at 915; Roberto Mazzoleni \& Richard R. Nelson, The Benefits and Costs of Strong Patent Protection: A Contribution to the Current Debate, 27 RES. POL'Y 273, 274 (1998); Brian D. Wright, The Economics of Invention Incentives: Patents, Prizes, and Research Contracts, 73 AM. ECON. REv. 691, 696 (1983).

95. See, e.g., SUZZANNE SCOTCHMER, INNOVATION AND INCENTIVES 138-43 (2004). 
entrepreneurial activities. ${ }^{96}$ So, if as our findings suggest, patents provide relatively weak incentives to undertake the risks of innovation, what purposes do they serve?

\section{The Multiple Meanings of Startup Patenting}

The overall picture of startup patenting suggested by these two chief findings is surprising. On the one hand, startup companies in all high technology sectors are patenting much more widely, and in greater numbers than we had reason to believe from the prior literature. However, when we ask top executives at these early-stage firms whether the patents that they are seeking (and for which they are devoting scarce resources) offer incentives to create, develop, and commercialize the technology that is at the core of the venture, they answer that, in general, patents are not serving that purpose particularly well.

Our questionnaire design enabled us to shed light on this important conundrum. We find, and detail below, that patents are playing significant roles in technology entrepreneurship, even if the executives of startups assess their incentive value to be relatively weak. Some of these functions do concern patents' traditional role in diminishing competition from third parties in the technological marketplace and the related concern of securing profits from innovation-especially for biotechnology, medical device, and hardware firms (but notably less so for software and Internet companies). At the same time, patents appear to be supporting other activities crucial to technology startups: securing the necessary investment to develop and grow; increasing the odds and quality of a liquidity event, such as an acquisition or IPO; and serving strategic roles in negotiation and defending against patent infringement suits.

What clearly springs from our data is a recognition that patents serve as important institutional support for activities that are important to the success of technology entrepreneurs. But as some theorists have recently suggested, ${ }^{97}$ for many of these companies, patents do not provide the sorts of incentives to innovate that we long expected, though our findings indicate that they often serve other important roles in the entrepreneurship process. We now turn to a fuller examination of these roles.

96. See generally Sichelman, supra note 3 (examining incentives to commercialize significant patented inventions).

97. See Clarisa Long, Patent Signals, 69 U. CHI. L. REV. 625 (2002); Mann, supra note 92. 


\section{FIRST FINDING: PATENTS HELP STARTUPS IN TECHNOLOGICAL COMPETITION}

\section{A. Patents Can Serve to Promote Startups' Competitive ADVANTAGE}

A major finding of our survey, and a partial explanation for the widespread use of patents by technology entrepreneurs, concerns the function that patents serve in helping the startup compete in the marketplace with its innovative technology. Theory has long suggested that formal IP rights are critical in protecting the lead-time or first-mover advantages that fast innovators possess. ${ }^{98}$ Moreover, earlier surveys of managers at large U.S. companies indicated that IP rights are an important means of gaining a competitive edge but found mixed results when specifically considering patents. $^{99}$

Our results demonstrate that patenting plays a substantial role for many high-technology startups in securing competitive advantage from their technology innovations, but that this finding is also context-specific. In asking our sample companies about how meaningful patents were in the quest for profits and success, we attempted to disaggregate some of the answers from previous surveys, and also focused on startups. Specifically, previous studies tended to examine how mainly large and publicly traded U.S. companies profit from their innovation in fairly broad terms, ${ }^{100}$ generally failing to distinguish among important legal mechanisms, such as copyrights and trademarks. ${ }^{101}$ While making these distinctions, our questionnaire also reproduced several elements from these previous surveys, such as "patenting" and "secrecy," for the sake of consistency and comparison. ${ }^{102}$ In the end, our questionnaire asked the respondent to indicate how important (or unimportant) the following seven items were to the company in securing

98. See Teece, supra note 10 , at 286-87 (suggesting that both technological complexity and the strength of IP rights are critical to protect the innovator's advantage).

99. See Cohen et al., supra note 24; Levin et al., supra note 24.

100. See supra note 99.

101. For example, the study by Levin and others included both patenting and secrecy, but not copyrights and trademarks as appropriability means. See Levin et al., supra note 24, at 794. The study by Cohen included patenting, secrecy, and "other legal" means. Cohen et al., supra note 24 , at 5-6.

102. The use in prior surveys of the term "secrecy" instead of "trade secret" presented us with a conundrum: we believed that the term "secrecy" could be interpreted by respondents to mean both more, and less, than "trade secret." At the same time, we saw value in being as consistent as possible with prior surveys. Preliminary testing with respondents convinced us that the subjective understanding of the terms "secrecy" and "trade secret" did not differ substantially among respondents. As such, we decided to use the term "secrecy." 
competitive advantage from its technology innovations: first-mover advantage over competitors; secrecy; patents; copyrights; trademarks; difficulty of reverse engineering; and other production, implementation, or marketing capabilities. Hereafter, we call these seven methods "appropriability strategies." 103

Our results show that these early-stage firms use multiple appropriability strategies. Among our aggregated respondents, ${ }^{104}$ first-mover advantage is clearly ranked the most important: in fact, it is the only appropriability strategy ranked between "moderately important" and "very important" on average by all companies. ${ }^{105}$ Three methods are grouped together in the next ranked position-secrecy, complementary assets, and patenting-which respondents rate on average between "slightly important" and "moderately important," although closer to the latter. ${ }^{106}$ Following these are the remaining three appropriability strategies-difficulty of reverse engineering, trademarks, and copyright-which fall between "slightly important" and "moderately important." 107

Such an aggregation of our responses ${ }^{108}$ offers a basic descriptive picture into our results: first-mover advantage tends to dominate the other appropriability strategies. This view of our data also suggests that other methods-including patents - are generally rated as having some importance. In fact, the difference between the average scores assigned to the other six methods is relatively small (even though some of these differences are statistically significant). However, this aggregation of our responses hides a highly nuanced story. In fact, when we examine companies' responses by their differing characteristics, such as their technological focus or the type of funding they have secured, the importance of these appropriability strategies, and pointedly patenting, tends to shift radically.

103. In so doing, we follow the nomenclature of the Cohen study. See Cohen et al., supra note 24 , at 5 .

104. 1,236 companies responded to this set of questions.

105. Scoring at the mean 3.3 on a $1-4$ scale; significantly different from the next-ranked method at the $99 \%$ confidence interval.

106. These methods score at the mean $2.8,2.8$, and 2.7 , respectively, on a $1-4$ scale; these three are not significantly different from each other, but are significantly different from the next ranked method at the $99 \%$ confidence interval.

107. These methods score at the mean $2.6,2.5$, and 2.5 , respectively, on a $1-4$ scale; these three are not significantly different from each other in rank order, but the mean score for reverse engineering is significantly different from the mean score for copyright at the $99 \%$ confidence interval.

108. See supra note 104. 
Figure 1: Capturing Competitive Advantage from Technology, by Industry ${ }^{109}$

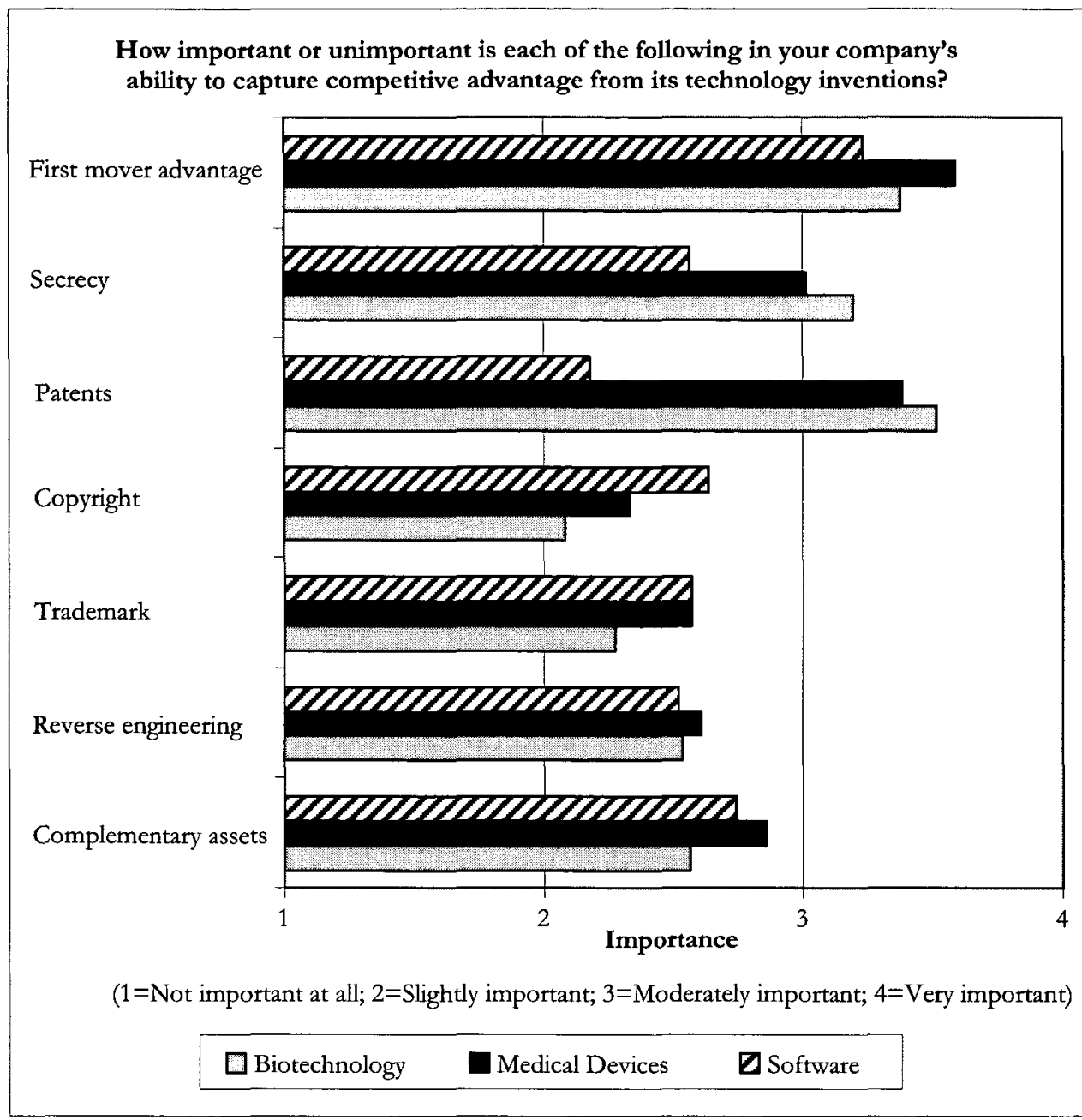

1. Industry Influences Patents' Role in Competitive Advantage

One cut of our data that allows us to see profound differences in the reported importance of patents, as well as other appropriability strategies, is segmenting by industry: for biotechnology, medical devices, and even IT hardware firms in our sample, ${ }^{110}$ patenting is ranked among the most important appropriability means (Figure 1). Among biotechnology

110. We note that IT hardware companies are found only in our VentureXpert sample, and thus their responses presented here must be viewed through the overall lens of the increased likelihood of venture-funded firms to use the patent system. 
companies, patenting is ranked the most important appropriability strategy. ${ }^{111}$ For medical device startups and venture-backed IT hardware companies, respondents rank patenting second, behind first-mover advantage. ${ }^{112}$

Our results, for all biotechnology companies combined, underscore that a firm's technological focus strongly influences startup executives' view of the importance of different appropriability strategies. For this group of firms, patenting is ranked as the most important means of capturing competitive advantage. ${ }^{113}$ Even when we exclude the VentureXpert firms and focus only on the D\&B firms, patenting is still rated the most important appropriability method. ${ }^{114}$ This finding is noteworthy given that, among the sample of both large and small pharmaceutical firms reported by Cohen, Nelson, and Walsh ("Cohen et al."), patenting was considered less effective than secrecy in protecting competitive advantage from innovation. ${ }^{115}$

We were also surprised to find that the importance of patenting by (venture-backed) IT hardware companies is much more similar to that expressed by healthcare startups than by software and Internet companies. ${ }^{116}$ This is a noteworthy finding because in the 1994 Carnegie-Mellon Survey, IT

111. The difference over the second most important, "first-mover advantage," is statistically significant at the $90 \%$ confidence interval.

112. In both cases, the differences between patenting and first-mover advantage were significant at the $95 \%$ confidence interval. The results for all medical device firms show that patenting is more important than the next most important method cited, secrecy, with a difference significant at the $99 \%$ level. Among the VentureXpert IT hardware firms, patenting was indistinguishable in importance from secrecy and reverse engineering, with all three essentially "tied" for the second most important means-although each was significantly different from the next most important method, complementary assets, at the $95 \%$ confidence interval.

113. Among these 171 respondents, "patents" is ranked first, and is significantly different from the second ranked "first-mover advantage" at the $90 \%$ confidence level.

114. However, among the $101 \mathrm{D} \& \mathrm{~B}$ companies responding to this question, we cannot statistically differentiate between first-mover advantage, secrecy, and patenting.

115. See Cohen et al., supra note 24. The study by Cohen et al. asked respondents to report on the "effectiveness" of appropriability means, while we chose to follow the study of Levin et al., supra note 24 , and ask about their "importance." While comparison is made more difficult by these semantic differences, Cohen et al. nevertheless report that patenting is a less effective appropriability strategy for product innovation, and particularly for process innovation, than secrecy. See Cohen et al., supra note 24, at 9-11. Although not discussed in the Cohen et al. working paper, the original Carnegie-Mellon survey reportedly contained responses from some biotechnology firms indicating that in 1994, secrecy was substantially more effective than patenting-more so in fact than among larger pharmaceutical firms. Communication from Wesley M. Cohen, Professor, Duke Univ., to Stuart Graham, Assistant Professor, Ga. Inst. Tech. Coll. Mgmt. (Aug. 12, 2009) (on file with authors).

116. We note that IT hardware firm responses exist only in the VentureXpert data, and that no D\&B "hardware" respondents exist in our sample, so the reported averages represent only venture-backed companies. 
hardware firms (such as semiconductors and communications equipment) reported that patenting was only effective at protecting about one-quarter of their product innovations, compared with secrecy, which was effective at protecting about one-half. ${ }^{117}$ In our results, venture-backed IT hardware firms rank patenting at least as important as secrecy. ${ }^{118} \mathrm{Clearly}$, for this select sample of IT hardware companies, patenting plays a much more significant role in capturing competitive advantage from innovation than for a sample of generally larger firms surveyed by Cohen et al. over a decade ago. ${ }^{119}$ Like the biotechnology companies, part of this difference may reflect our respondents' small size and lack of reliance upon complementary assets. Another explanation could lie in industry shifts, such as an increasing trend in intra-industry cross-licensing, as well as the rise of "fabless" semiconductor firms, which appear to be more dependent on patents than secrecy since they are more likely to license, rather than commercialize, their inventions. ${ }^{120}$

The value of patenting among startups in biotechnology and medical devices (and venture-backed IT hardware) stands in stark contrast to the (un)importance ascribed to patents by software and Internet firms. The limited function served by patenting in technology competition for earlystage software firms is underscored in Figure 1. In software, patenting is rated the least important among all the appropriability strategies. ${ }^{121}$ When we focus only on software companies in the D\&B sample, patenting is still the least important method, ${ }^{122}$ ranked on average barely above "slightly important." Likewise, patenting is the lowest-rated method by venture-

117. But, interestingly, undifferentiated "computer" companies in the Cohen et al. survey reported that both patenting and secrecy were about equally effective. Cohen et al., supra note 24 , at tbls. 1 \& 2 .

118. While the average importance given to patents is greater than that of secrecy, the difference is not statistically significant at conventional levels.

119. See Cohen et al., supra note 24 , at tbls. 1 \& 2. Interestingly, in our findings, preventing reverse engineering-presumably through technical design-is more important to competitive advantage for IT hardware startups than to companies in other sectors.

120. See Ashish Arora \& Marco Ceccagnoli, Patent Protection, Complementary Assets, and Firms' Incentives for Technology Licensing, 52 MGMT. SCI. 293, 293 (2006); Bronwyn H. Hall \& Rosemarie Ham Ziedonis, The Patent Paradox Revisited: An Empirical Study of Patenting in the U.S. Semiconductor Industry, 1979-1995, 32 RAND J. ECON. 101, 107-08 (2001).

121. Patents are ranked last, with the difference between patenting and the next lowest ranked method, reverse engineering, significant at the $99 \%$ confidence interval.

122. For both the overall and $D \& B$ sample of software firms, patenting is rated the lowest by statistically significant margins (at the $99 \%$ confidence interval). 
backed software companies, although for these companies it is not statistically different from other low-ranked methods. ${ }^{123}$

\section{Patents' Role in Technology Competition Differs by Innovation Focus}

We find that "product innovators" are substantially more likely than "process innovators" to report that patenting is important in capturing competitive advantage. ${ }^{124}$ To relate the aforementioned appropriability strategies with the innovation focus of early-stage companies, we asked our respondents to disclose the importance (or unimportance) of various sources of innovation to their overall business strategy. ${ }^{125}$ For two of these categories, product and process innovation, we were able to identify companies considering one or the other as their primary innovation focus.

Our analysis demonstrates that, in general, patenting is almost twice as important for product innovators than for process innovators. In fact, patenting is rated as second only to first-mover advantage by product innovators, but is rated last by process innovators. First-mover advantage, secrecy, copyright, trademark, and the difficulty of reverse-engineering are also rated as more important by product than by process innovators, ${ }^{126}$ but not to the same extent as the differential reported in the importance of patenting between the two types of innovators. Among all the methods, only complementary assets are ranked (in absolute terms) as a more important appropriability strategy by process innovators when compared with product innovators. ${ }^{127}$

Noting that biotechnology companies rated patenting as more important overall than did software and Internet firms, we also examined product innovators within each of these two technologies. A strong technology effect on the ranking of the importance of patents is once again evident: biotechnology product innovators are much more likely to rate patents as

123. Venture-backed software firms rank "patents" on average the lowest in importance, but their average ranking is not statistically different from "copyright" and "trademark." Patenting is statistically different from the next most lowly ranked method, "secrecy," at the $95 \%$ confidence interval.

124. We define "product innovators" here as those that rated product innovation as "very important" but all other types of innovation as less important. Similarly, we define "process innovetors" as those that rated process innovation as "very important" but all other types of innovation as less important.

125. These included: (1) product innovation; (2) process or internal tools innovation; (3) business-model innovation; and (4) design innovation (including product shape and packaging).

126. The differences associated with copyright and trademark are not statistically significant at conventional levels.

127. This difference is not statistically significant at conventional levels. 
important when compared with software product innovators. Among these product-focused biotechnology companies, patenting was rated the most important appropriability strategy. Among product-focused software companies, however, patenting remains rated the least important means of successfully competing. Therefore, we believe that our main findings are driven more by technology differences than the type (i.e., process vs. product) of innovation.

\section{Startups Use Multiple Methods to Compete with Technology Innovations}

As was clear in the aggregated statistics presented earlier, startups across the high-technology landscape use different methods to compete in the marketplace. While patenting is playing a substantial role in all but the software and Internet sector, startups in all sectors use other appropriability strategies-possibly in complementary ways. It is noteworthy, however, that software and Internet startups, compared with companies in other sectors, tend to rate all methods about which we queried as less important. Software and Internet companies rate on average only one method, first-mover advantage, as at least "moderately important." Conversely, companies in other industry sectors rate at least three methods on average as more than "moderately important" (Figure 1).

Our in-depth interviews with respondents support these observations. One executive at a biotechnology startup-we will call him Glen-reported that the company held over 150 patents, many of which his company filed, but a substantial number of which were acquired from other entities. In describing his company's competitive strategy, he reported:

We have three tiers when thinking about how to protect our technology with intellectual property. Tier one comprises [our basic technologies]; tier two involves the "clumping" of our [basic technologies]; tier three is a combination [of our technologies] to very specific uses. Beyond these, we adopt different strategies for different products and for different reasons. For one, we file [fewer] manufacturing patents in hopes of keeping these as trade secrets. ${ }^{128}$

Glen also related that, while first-mover advantage is a key component of his company's strategy, "[first-mover advantage] plays more of a role in the drug industry than it does in biotech .... It is also important [for us] to establish relationships within the network of similar companies and investors. Finding key partners is critical for a platform company like us." ${ }^{\text {129 }}$

128. Interview with anonymous company founder (Mar. 2009).

129. Id. 
These comments reflect several findings that arise from our survey results. While biotechnology firms are active patent-holders and are more likely to say that patents are important to their competitive position, they also tend to rank several, if not all, of the various means of capturing competitive advantage from technological innovation more highly relative to software companies. Moreover, to effectively compete, startups tend to report that multiple methods of appropriability are useful, even though the clustering of and relative importance ascribed to these methods do not follow a common pattern.

For instance, in terms of startups' use of intellectual property; it is noteworthy that both copyrights and trademarks play varied appropriability roles. These forms of protection are particularly salient for software firms, although even in this sector there is divergence. Among the population of software companies (as proxied by $\mathrm{D} \& \mathrm{~B}$ ), executives rate copyright as second, not statistically different from complementary assets (but both methods ranked behind first-mover advantage, which is clearly rated as the most important method). ${ }^{130}$ For these same software-firm respondents, trademarks rank just behind copyrights and complementary assets, and are considered just as important as secrecy in capturing competitive advantage. Among venture-backed software firms, however, trademarks, copyrights, and patents are ranked behind all others, statistically undifferentiated among each other as the least important methods of capturing competitive advantage. The responses of $D \& B$ software companies differ markedly not only from venture-backed software firms, but also from all companies in other sectors. Among non-software startups, copyright protection is rated the least important of the several methods, while trademarks tend to be among the lower-ranked items.

In sum, while we find that various appropriability strategies are important to technology startups, our chief finding is that, outside of the software and Internet sector, patenting plays a substantial role in helping early-stage technology companies compete. But having learned that patenting is important in securing competitive advantage does not answer a key question: What are the specific mechanisms by which this competitive advantage is achieved? Is competitive advantage attained through added financing that patents help facilitate for the company, thus enabling it to develop a better technology and get it to market faster and more effectively than its competitors? Or is this competitive advantage won when a patent signals to suppliers and would-be customers that a company has a valuable and

130. These differences are significant at the $99 \%$ confidence interval. 
important technology? Or do patents permit the company to secure its innovations, and keep competitors at bay while it develops a monopoly position that patents then serve to protect and solidify? We could answer these questions only by inquiring into the specific factors motivating companies seeking patent protection on their innovations. As such, we asked our respondents whose companies had actually filed at least one U.S. patent application about the reasons they pursued a patenting strategy.

\section{SECOND FINDING: STARTUPS HAVE DIFFERING MOTIVES FOR PATENTING}

We find that when technology entrepreneurs seek patent protection, they often do so for varying and, sometimes, complementary reasons. Comments made by Glen, the CEO of a biotechnology firm holding over 150 patents, are illustrative:

We have a patent committee that decides, within a complex framework of factors, whether it is important to patent, whether competitors will copy the technology regardless of IP protection, and whether the patent will have foreseeable future value.... Patents also tend to legitimate [our product]. A patent can also provide a source of supplementary income and can be a badge, a branding, of a successful innovative high-tech company. ${ }^{131}$

Glen also told us that patents are important to his company when making deals and seeking investment:

When doing deals, sometimes we only show our stack [of patents], and sometimes the other party wants to do a lot of due diligence on our individual patents. But we never fail to give a presentation of about one hour on them-patents play a huge role in securing investment. ${ }^{132}$

He also indicated how the issues of investment, copying, and competition were interrelated in the ways his company approached patenting:

I have fidelity in my investors, and have raised over $\$ 100$ million in capital. In securing my investors' support, I see our patent portfolio as an integral piece of the puzzle. Our competitors are concerned about our patents, or otherwise they'd do it themselves. Our customers don't really care-they just want the best product at the cheapest price. But if startups like ours are not diligent about securing patents, they will be crushed by larger

131. Interview with anonymous company founder, supra note 128.

132. Id. 
corporations, who will steal your technology and make it cheaperand obliterate you. ${ }^{133}$

This chief executive's comments touch upon several of the factors that our study of the literature and our pre-survey conversations with entrepreneurs and investors suggested were motivators for startups to seek patent protection. During this process, we identified those factors that were most prominent, including the following: preventing others from copying products or services; improving the chances of securing investment; obtaining licensing revenues; improving the chances/quality of liquidity (e.g., acquisition/IPO); preventing patent infringement actions against the company; improving the company's negotiating position with other companies (e.g., cross-licensing); and enhancing the company's reputation/product image. In the survey, we asked whether the company had filed at least one patent, and among those answering in the affirmative, we inquired into the importance of these several motivations for patenting. ${ }^{134}$

\section{A. Startups File Patents to Prevent Copying, Secure Financial GOALS, AND ENHANCE REPUTATION}

Across all respondents who report filing for patents, ${ }^{135}$ the most important reason for patenting is to prevent others from copying the startup's products and services (Figure 2). ${ }^{136}$ This result is notable because it contradicts some prior anecdotal reports indicating that the high costs of patenting and enforcing patents generally precluded startups from using patents to prevent copying and competition..$^{137}$ We approach this finding with a certain amount of caution, however, since we are mindful that the premier position given by our respondents to "preventing copying" may be at least in part the result of socially desirable response bias (in that respondents generally know patents are supposed to prevent copying and so tell us that they do just that). ${ }^{138}$ Our qualitative interviews with respondents, however,

133. Id.

134. See also Sichelman \& Graham, supra note 11 (providing a more detailed account of the survey findings on the motivations to patent).

135. 610 companies responded to this set of questions.

136. The mean for this response was statistically different from the next most important (securing investment) at a $99 \%$ confidence level.

137. See Mann, supra note 92, at 981 (finding that the benefits of patenting to earning supernormal profits are weak for startup software firms, especially for ones at very early stages).

138. Communication from Wesley M. Cohen, Professor, Duke Univ., to Stuart Graham, Assistant Professor, Ga. Tech. Coll. Mgmt. \& Ted Sichelman, Assistant Professor, Univ. San Diego, Sch. Law (July 22, 2009) (on file with authors). See generally Catherine E. Ross \& John Mirowsky, Socially-Desirable Response and Acquiescence in a Cross-Cultural Survey of Mental Health, 
offer us confidence that preventing copying is an important consideration when startups choose to patent.

Next in importance is a cluster of several motives: improving chances of securing investment; improving chances and quality of a liquidity event (another species of securing capital); ${ }^{139}$ and, of somewhat lesser importance, enhancing company reputation and product image. ${ }^{140}$ This latter result, in which financial motives dominate reputation, is driven entirely by the VentureXpert companies in our survey. When we consider only $\mathrm{D} \& \mathrm{~B}$ respondents, enhancing reputation is indistinguishable from securing funding and improving liquidity, although among the D\&B startups, preventing copying is still the most important reason reported for filing patents.

25 J. HEALTH \& SOC. BEHAV. 189 (1984) (noting the incidence of socially-desirable response bias). Further support for such a view is lent by our positioning the "preventing copying" choice as the first among our set of options presenting in the questionnaire.

139. We consider the "liquidity event" here as a means of securing capital for growth. We recognize, of course, that successful exit can also provide a return on investment for financiers and personal wealth for founders and employees.

140. There were no statistically significant differences between the rankings of securing investment and improving the liquidity event, but enhancing company reputation ranks as significantly different from both of these former reasons at a $95 \%$ confidence level. 
Figure 2: Motivations for Patenting - All Startups Filing Patents

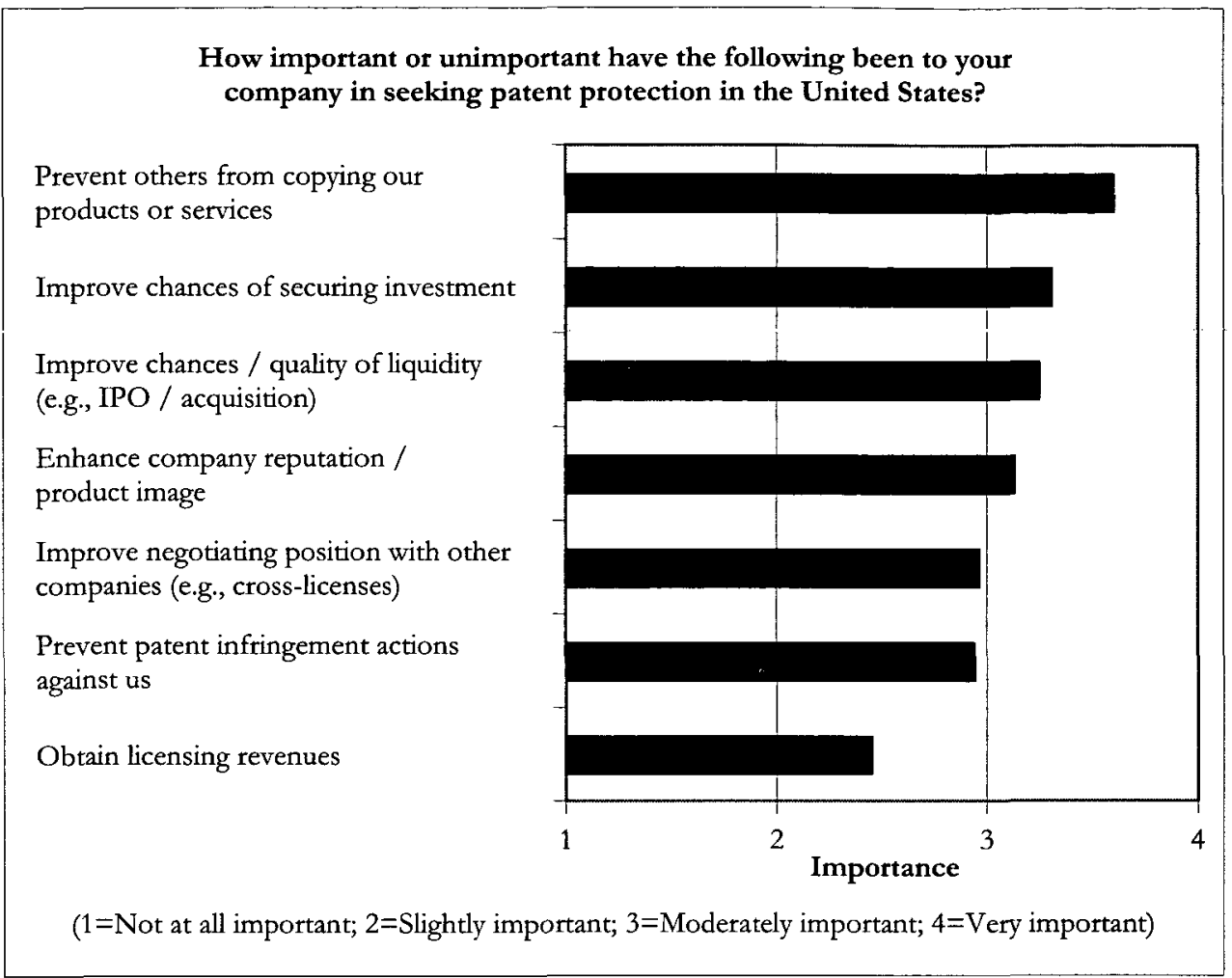

The above question was asked of those reporting that their company had filed for at least one U.S. patent (averages reported).

These results contrast with earlier large-firm surveys in which respondents ranked patenting for securing capital as relatively unimportant. ${ }^{141}$ Our results are consistent, however, with a finding in the Carnegie Mellon survey showing that relatively smaller firms in that study tended to rank the importance of patenting to enhance firm reputation as significantly higher than did larger firms. ${ }^{142}$ Our findings are also consistent with studies showing that patenting plays a positive role in valuation during fundraising and upon exit for venture-backed firms. ${ }^{143}$

The qualitative interviews we conducted with respondents following the administration of our survey add flavor to these findings. Patenting to prevent copying was an important motivator for the CEO of a software firm,

141. There is a slightly stronger tendency by the venture-backed firms to rate improving the chances of securing investment and liquidity events as more important than the D\&B firms. However, the order of the reasons listed is the same for each sample set as the aggregate presented above.

142. See Cohen et al., supra note 24 , at 18 n.41.

143. See Cockburn \& MacGarvie, supra note 44, at 42; Hsu \& Ziedonis, supra note 3, at 2. 
whom we call Anna. She created a piece of software and filed a patent prior to founding a startup to market the software in 2003. That patent became important to her company's survival and success. Anna relates:

A large public company copied the code of our product and tried to sell it on the market.... Without my patent, I wouldn't have been able to stop it .... [Ultimately], our company settled on the courthouse steps-literally-and we got our expenses covered, picked up a bit of money, and also established a license agreement [with the large company] to license it and pay us royalties. ${ }^{144}$

Regarding the relationship of patenting to entrepreneurial capital, she remarked: "Venture capital investors place a high value on companies with patents. From 2003 through 2007, I sat in on many startup and venture capital boards and, generally speaking, I found that patents were key to funding-in fact, they were the differentiator between companies."145 These comments mirror our general findings that motivations to patent are varied, but that "preventing copying" and "financing and reputation" motives loom large for startups.

The next most important reasons for technology startups to file patents deal with defensive and strategic motives ${ }^{166}$ - namely, to prevent infringement lawsuits and to improve negotiating position, for example in cross-licensing deals (Figure 2). ${ }^{147}$ That startup and early-stage firms rate these motives for patenting as "moderately important" is a novel finding, insofar as previous work had implicitly assumed-at least outside of the biotechnology industry-that these firms were not targeted in enforcement (litigation and licensing) activity at sufficiently high rates to justify using patents defensively. ${ }^{148}$ Although it appears that our early-stage technology firms state that these motives for patenting are less important than reported in earlier surveys of larger firms, ${ }^{149}$ our result that startup companies may be

144. Interview with anonymous company executive (Apr. 2009).

145. Id.

146. While the means of both of these motivations are significantly different at the $99 \%$ confidence level from that of "enhancing reputation," there are no statistically significant differences between the two reasons. Taking the lesser important reason of this grouppreventing patent actions against us-there was a statistically significant difference at the $99 \%$ confidence level when compared with the next most important reason-licensing.

147. We are unable to differentiate, however, whether the "negotiation" value of patents is related to strategic motives or reflects the "deal-making" aspects of financing and the exit event mentioned earlier.

148. See Graham \& Sichelman, supra note 5, at 1096 ("We would be somewhat surprised if many start-ups are filing for patents to improve their position in cross-licensing negotiations ....").

149. See Cohen et al., supra note 24 , at tbls.8, 9, 10 \& 11 . 
engaging in sophisticated uses of patents for strategic and defensive purposes is nonetheless noteworthy and deserves further study.

Figure 3: Motivations for Seeking Patent Protection, by D\&B Industry

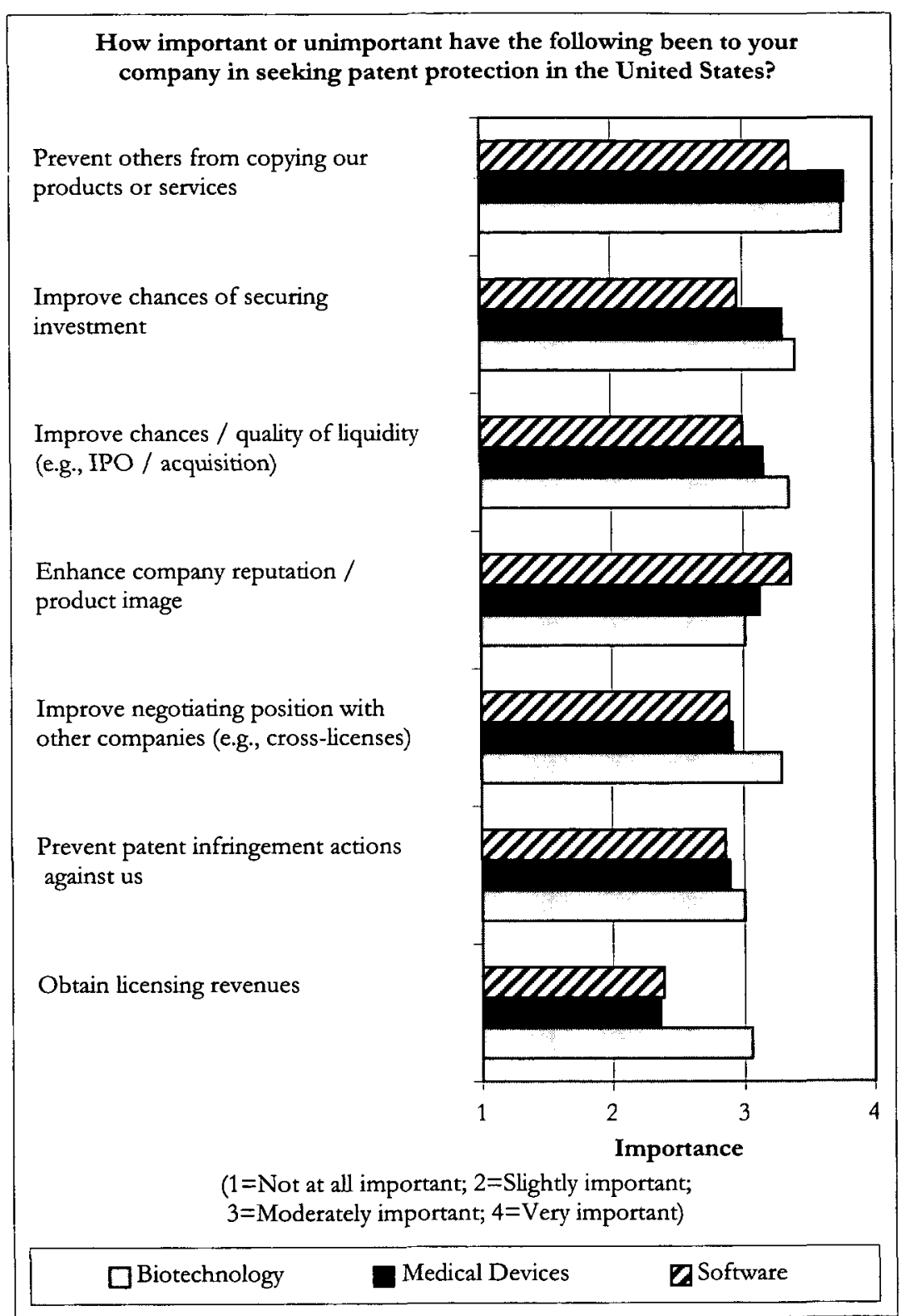

Question asked of those reporting that their company had filed for at least one U.S. patent (averages reported).

Finally, all startups rated the importance of securing licensing revenue significantly lower than other reasons, with the mean of all respondents falling between "slightly important" and "moderately important." This 
finding might seem to conflict with the markets-for-technology view that small firms are more likely to license their patents because vertical specialization allows these firms to operate in upstream technology markets and provide technology inputs to (generally large) firms operating in downstream product markets. ${ }^{150}$ Indeed, a recent survey of European patentees showed that small firms are much more likely to patent to secure licensing revenue than larger ones. ${ }^{151}$ While our main findings show that licensing revenue is generally a comparatively unimportant consideration in startup patenting, some evidence from our study supports the view that the smallest of startup firms rely more on patenting for licensing than larger firms. ${ }^{152}$ And as we detail in the next Section, firms in the biotechnology industry-which is often used as an exemplar of vertical specialization-are more likely to rate licensing income as an important reason to patent than are firms in other sectors we surveyed.

\section{B. Startups' Motivations to Seek Patents Differ by INDUStRY}

Consistent with the anecdotes we collected during our qualitative interviews, our results also show significant inter-industry differences in the motives for filing patents (Figure 3). We find that the health and life science companies (biotechnology and medical devices) tend to cluster in the importance they ascribe to the different motives. From a statistical standpoint, the averages presented in Figure 3 for biotechnology and medical device respondents are indistinguishable, with the exception of "obtaining licensing revenues" and "improving negotiating position," which biotechnology firms rate as significantly more important motivations to file patents. ${ }^{153}$ Highlighting the industry distinctions, software and Internet firms' answers are all significantly different from the biotechnology and medical device firms, with the exception of "preventing patent infringement actions. $" 154$

In particular, biotechnology and medical device firms list preventing copying as nearly "very important" overall, while software firms place less emphasis on this motive (though still rating it between "moderately" and

150. See, e.g., Arora \& Ceccagnoli, supra note 120, at 304-05.

151. See Alfonso Gambardella et al., The Value of European Patents: EVIDENCE FROM A SURVEY OF EUROPEAN INVENTORS 41 (2005), available at http://www.alfonsogambardella.it/PATVALFinalReport.pdf.

152. When we segment our respondent firms by total revenue, high-revenue entrepreneurial firms report that licensing is significantly less important to patenting than for low-revenue firms. See Sichelman \& Graham, supra note 11.

153. These differences are significant at the $99 \%$ and $95 \%$ level of confidence, respectively.

154. These differences are significant at the $95 \%$ confidence interval or above. 
"very" important). ${ }^{155}$ The biotechnology and medical device companies also cite patenting to secure investment and to improve the chances and quality of a liquidity event as much more important motivations than do software firms. ${ }^{156}$ Finally, biotechnology firms place much greater emphasis on patenting to obtain licensing revenue than all other firms, including medical device firms. ${ }^{157}$

\section{Patents SERVE an Important FunCtion in the FinANCing of STARTUPS}

Another noteworthy finding of our study is that patents play an important role in the financing of many startup companies, both during the initial stages and subsequent development of the firm, and also at the liquidity or exit event. Entrepreneurs and startup firms can face substantial barriers when seeking to secure the financial resources necessary to grow and to survive, largely due to their small size and limited experience. ${ }^{158}$ Compounding these problems, startups often lack observable measures of success since they generally have few assets and little to no operating history. ${ }^{159}$ The uncertainty created by this limited information makes it difficult for potential investors to appraise the quality and profit potential of the enterprise, and as a result, these investors must assess the value of startups through other readily available measures. ${ }^{160}$

Several commentators have suggested that patents can serve as quality signals for startup investors. ${ }^{161}$ For instance, David Hsu and Rosemarie Ziedonis have recognized that while many characteristics of the firm can be used as quality signals associated with future profits, patents have been

155. Biotechnology and medical device firms showed statistically significant differences in their mean responses for the importance of preventing copying from hardware and software firms at a $99 \%$ confidence level.

156. Biotechnology and medical device firms showed statistically significant differences from hardware and software firms at a $99 \%$ confidence level.

157. Biotechnology firms showed statistically significant differences from medical device, hardware, and software firms at a $99 \%$ confidence level.

158. See A.L. Stinchcombe, Social Structure and Onganizations, in HANDBOOK OF OrgaNiZATIONS 142-93 (James G. March ed., 1965).

159. See Tyzoon T. Tyebjee \& Albert V. Bruno, A Model of Venture Capitalist Investment Activity, 30 MGMT. SCI. 1051, 1053 (1984).

160. See Toby E. Stuart, Ha Hoang \& Ralph C. Hybels, Interonganizational Endorsements and the Performance of Entrepreneurial Ventures, 44 ADMIN. SCI. Q. 315 (1999).

161. See Hsu \& Ziedonis, supra note 3, at 1-2 (suggesting that entrepreneurial lineage, founder backgrounds, and affiliations with reputable third parties such as corporate partners, venture capitalists, and investment bankers, can serve as important quality signals); Long, supra note 97, at 655-59 (setting forth a "signaling" theory of patents). 
underappreciated in that role. ${ }^{162}$ Moreover, patents are costly assets, and therefore fit the cost criteria for a quality signal laid out by Michael Spence, who suggested that a credible signal ought to be costly, both in terms of direct pecuniary costs and effort. ${ }^{163}$

While these theories can be read to apply to many types of investments, existing empirical tests of the value of patents tend to examine only venture capital, a species of investment that comprises a relatively small slice of the overall entrepreneurial finance pie. ${ }^{164}$ In contrast to relatively difficult-tosecure VC financing, startups are more often funded by angel investors and commercial banks, and most often by friends and family. ${ }^{165}$ The Kauffman Foundation Firm Survey, which tracks a cohort of companies founded in 2004 , shows that while $1 \%$ and $5 \%$ of companies started in their founding year by exchanging ownership in the company for VC and angel funding, respectively, $7 \%$ took personal loans from friends and family, 13\% supported the founding with personal loans, and 39\% used personal credit cards to finance at least some part of the startup. ${ }^{166}$

\section{Investors and Entrepreneurs Highlight the Role of Patents in Startup Financing}

Unlike previous studies, our survey examined various sources of startup investment, and the results show that patenting plays a more substantial role in supporting many different species of entrepreneurial capital investment than has been commonly believed. Several of the qualitative interviews we conducted illuminate this finding. For instance, the partner we call Stan, who works with a VC firm and invests primarily in life-science companies, told us,

When thinking about the life-cycle of a company, in many respects the value of the IP is really generally assessed at the early stage by the first stages of "professional" money. These early-stage

162. See Hsu \& Ziedonis, supra note 3, at 10-12.

163. Michael Spence, Job Market Signaling, 87 Q.J. ECON. 355, 358 (1973).

164. See, e.g., Dirk Engel \& Max Keilbach, Firm-Level Implications of Early Stage Venture Capital Investment - An Empirical Investigation, 14 J. EMPIRICAL FIN. 150 (2007); Paul Gompers \& Josh Lerner, The Venture Capital Revolution, 15 J. ECON. PERSP. 145 (2001); Steven N. Kaplan \& Per Strömberg, Financial Contracting Theory Meets the Real World: An Empirical Analysis of Venture Capital Contracts, 70 REV. ECON. STUD. 281 (2003). But see Bernard S. Black \& Ronald J. Gilson, Venture Capital and the Structure of Capital Markets: Banks Versus Stock Markets, 47 J. FIN. ECON. 243 (1998).

165. Alicia Robb \& David T. Robinson, The Capital Structure Decisions of New Firms (Feb. 11, 2009) (unpublished manuscript, on file with Social Science Research Network), available at http://ssm.com/abstract $=1345895$.

166. Alicia Robb \& David DesRoches, Kauffman Firm Survey - Baseline/First/Second/Third Follow-Up 446-48, 459-63 (Apr. 27, 2009) (unpublished manuscript, on file with Social Science Research Network), available at http://ssrn.com/abstract $=1024312$. 
[professional investors] will do a great deal of scrutiny of IP of all types, but especially of trade secrets and patents. If you think about a patent estate as having a life, most of its validity is presumably established when the first guys do their investment. Later investors experience less need to invest as much effort into due diligence as the early-stage investors did-there's generally no need to go back and repeat what's already been done. What will happen is that later investors will look at marginal change in the patents of a company since the last investigation.... A reason why patents are so important in the biotechnology industry in particular is that, when one makes a biotech investment, fundamentally one is making an IP investment. Consequentially, the early-stage venture investors dig very deeply into the validity of that IP. ${ }^{167}$

These comments resonate with our empirical findings: investors of many types value patents as an input into their investment decision, particularly venture capital investors in the life sciences.

Startup executives whom we interviewed also remarked about the importance that patents play in convincing investors to fund the startup. Neil, the CEO of a biometrics information company, suggested to us that "investors were interested in patents, and it was a key question that came up during negotiations. But our company does not hold patents as their [sic] core investment-instead we focus on our services to earn revenues." 168 This latter statement by Neil shows that there remains some ambiguity about the role played by patents in securing funding. Even among those companies that hold patents, we found similar ambiguity. For instance, our interview with Jeremy, the sole proprietor of a medical device company who filed one patent application, yielded this comment: "I applied for a patent to make it clear to investors what exactly it was that I owned. But seeing [the device] live is better than reading a patent, and I think that a live demonstration of [my device] is better in securing their investment."169

These comments from technology entrepreneurs are instructive, and help to highlight two important findings of our survey. First, patents appear to play a significant role in the funding decisions of many different types of startup investors. But, second, patenting may not be a necessary condition for access to entrepreneurial capital.

167. Interview with anonymous venture capital firm partner (May 2009).

168. Interview with anonymous executive (Mar. 2009).

169. Interview with anonymous founder (Feb. 2009). 


\section{The Role of Patents in Attracting Entrepreneurial Capital}

Our survey specifically asked respondents about the role that patents play in securing investment from six different sources: friends and family; angel investors; venture capital investors; other companies as investors (corporate venture capital); investment banks; and commercial banks (such as credit or loans). We inquired whether the company had engaged in negotiations with any of these six sources of startup capital and whether the company had been funded by that source. Moreover, we asked respondents to report whether each of the funding sources had indicated that the startup having patents was an "important factor" in that source's funding decision. ${ }^{170}$

a) Startups Report That Patents Are Important to Their Investors

Our respondents report that patenting plays a more significant role in attracting funding than had been previously believed. It is widely held that VC investors rely on patents in their investment decisions, although the reasons for this reliance are unclear. Some suggest that a patent is an important signal of quality in an uncertain investment environment, and that by relying on the independent expertise of the Patent Office, the investor can dispel some of the information asymmetries between the investor and the startup. ${ }^{171} \mathrm{~A}$ variant signaling theory maintains that while the Patent Office's pronouncements are not very meaningful, the fact that startup managers had the cognizance and wherewithal to file for patents is an important sign of their managerial sophistication, particularly in codifying inchoate knowledge. ${ }^{172}$ An alternative explanation is that patents tend to provide sufficient freedom to operate, allowing a company to develop and commercialize its embryonic products. ${ }^{173}$ Another theory suggests that

170. We understood that, like the problem of "hearsay," relying on one person's interpretation of the beliefs of another can be a problematic approach. In an attempt to mitigate against this problem, we asked the respondent whether the source had "indicated" that patents were an important factor.

171. See Hsu \& Ziedonis, supra note 3, at 5; Long, supra note 97, at 649.

172. See Graham \& Sichelman, supra note 5, at 1078-79.

173. See Gideon Parchomovsky, Publish or Perish, 98 MicH. L. REV. 926, 930 (2000). Technically, patents are only rights to exclude others from making, using, or selling the patented invention. 35 U.S.C. $\$ 271$ (2006). However, patents can also serve as "prior art" that can be used to prevent others from patenting. Thus, holding patents in a relevant field will tend to exclude others from patenting in that field, thereby providing the patent holder greater freedom to operate. Additionally, patents can enhance freedom to operate by preventing lawsuits from other patent holders, who might be wary of being countersued in litigation. See Graham \& Sichelman, supra note 5, at 1065. 
investors require the companies to have patents so as to enjoy these IP rights as residual claimants should the venture fail. ${ }^{174}$

While our data do not shed light on these different explanations per se, we are able to report some results on the perceived importance of patents in startup funding. ${ }^{175}$ Our figures reflect the share of those respondents who reported that a potential funding source (e.g., friends and family) with whom the respondent negotiated had indicated that having patents was important to their funding decision. For D\&B companies that negotiated with VC firms, just over two-thirds $(67 \%)$ had indicated to the respondent that patents were an important factor. This share is higher among our venture-backed sample, with just above three-quarters $(76 \%)$ indicating as much. There are also notable technology differences. Among the D\&B companies, $60 \%$ of software firms reported that VC investors considered patents important, while that figure rose to $73 \%$ for D\&B biotechnology firms and $85 \%$ for D\&B medical device companies.

Surprisingly, respondents reported that patents are also important to many commercial banks and "friends and family" investors. In our D\&B sample, companies negotiating with friends and family declare that $31 \%$ consider patenting important to making a funding decision. For those $\mathrm{D} \& \mathrm{~B}$ companies negotiating with commercial banks-presumably, mainly for loans or credit-the figure is just over one-fifth (21\%). The shares reported by the venture-backed sample are similar for friends and family $(35 \%)$, but increase markedly (49\%) for commercial banks. ${ }^{176}$

Our respondents also indicated that patents are important to other sources of entrepreneurial capital. D\&B companies report that $57 \%$ of angel investors, 54\% of "other companies" as investors, and 50\% of investment banks indicated that patents were important to their investment decision. Among our venture-backed sample, the figure for angel investors is similar to that for $\mathrm{D} \& \mathrm{~B}$ firms $(59 \%)$, but patents were reported to be significantly more important to investment banks (61\%) and other companies as investors $(70 \%){ }^{177}$

174. See id. at 1078.

175. The importance associated with "enhancing reputation" among the startups that filed at least one patent may reflect, at least in part, a desire by the company to become more attractive to investors.

176. The importance of patents to commercial banks among venture-backed firms may be indicative of recent trends in "venture debt." Datian M. Ibrahim, Debt as Venture Capital, 2010 U. ILL. L. REV. (forthcoming 2010), available at http://ssrn.com/abstract $=1418148$.

177. These differences are significant at the $90 \%$ and $99 \%$ confidence interval, respectively. 
b) Patents' Reported Importance to Investors Differs by Industry

As with other aspects of patenting by startups, the industry differences in the reported importance of patents to investors is noteworthy. Among $\mathrm{D} \& \mathrm{~B}$ biotechnology firms for instance, respondents were much more likely to reveal that commercial banks considered patenting by the target firm important (43\%) than were D\&B software firm respondents $(13 \%)$. This difference is also notable among friends and family, who considered patents to be important for more than half $(55 \%)$ of $\mathrm{D} \& \mathrm{~B}$ biotechnology firms, but less than one-quarter $(23 \%)$ of $\mathrm{D} \& \mathrm{~B}$ software companies. There are also significant differences for angel investors $(71 \%$ for biotechnology and 53\% for software), venture capital ( $73 \%$ and $60 \%$, respectively), other companies as investors ( $64 \%$ and $42 \%$, respectively), and investment banks (62\% and $36 \%$, respectively). Clearly, across all funding sources, respondents declare that potential investors view patenting as much less important for software and Internet as for biotechnology companies.

These industry differences are also marked in our venture-backed sample. Among the venture-backed biotechnology firms, for instance, friends and family were much more apt to indicate that patenting was important $(61 \%)$ than among venture-backed software firms $(18 \%)$. This difference is also notable in the responses concerning commercial banks, with companies reporting that this funding source indicated patenting as being important for almost three-quarters (74\%) of venture-backed biotechnology firms, but for less than one-third $(31 \%)$ of venture-backed software companies. There are also significant differences among angel investors $(78 \%$ for biotechnology and $36 \%$ for software), venture capital ( $97 \%$ and $59 \%$, respectively), other companies as investors ( $90 \%$ and $51 \%$, respectively), and investment banks ( $81 \%$ and $40 \%$, respectively).

In sum, our survey respondents report that patents are being widely demanded by different sources of entrepreneurial capital, though that demand does not extend to all funding negotiations, and the incidence of interest in patents is highly variable. While a caveat is in order-these findings are based upon the perceptions of the recipient about what was in the mind of the investor-the executives of the startups were nevertheless privy to negotiations, and can be expected to have unique insights into what occurred during their funding negotiations and what documents and information were requested of their companies. We are therefore reasonably 
confident that our data present at least a proximate window into the importance of patenting to various startup investors. ${ }^{178}$

\section{THIRD FINDING: TECHNOLOGY ENTREPRENEURS VARY IN THEIR REASONS FOR NOT SEEKING PATENTS}

There are several reasons for startup firms opting against patent protection, ${ }^{179}$ including the belief that the technology is not patentable; the high costs associated with prosecuting and enforcing the patent; the perception that, with reverse engineering, that patents may afford relatively weak protection; the fear of disclosure; ${ }^{180}$ and the availability of other forms of protection. ${ }^{181}$ Rather than simply asking our respondents that hold no patents to report on their motivations for choosing against patenting, we wanted to uncover the nuances underlying decisions to forgo patentingeven among those that were patenting other inventions. As such, all respondents were asked whether the last major technology innovation they did not patent was a product or a process (or not), and what reasons motivated their company's decision not to patent.

Our study of the literature and previous surveys, as well as discussions with entrepreneurs and investors, allowed us to generate a list of the most common reasons why, reportedly, startups choose not to patent their

178. In fact, our numbers may be biased downward. Although some investors may uncaringly request a firm's patents through pro forma "due diligence lists," because patent information is often publicly available, investors may often not disclose their interest in a firm's patents, rather than misrepresent concern when they have none.

179. For more analysis, see Sichelman \& Graham, supra note 11, which contains a more detailed discussion of our results on why startups choose not to patent.

180. Patenting is sometimes viewed as a "substitute" for secrecy, the former tending to vitiate any long-term attempts at secrecy through its disclosure requirements. See, e.g., David D. Friedman, William M. Landes \& Richard A. Posner, Some Economics of Trade Secret Law, 5 J. ECON. PERSP. 61 (1991). But of. Stuart J.H. Graham \& Deepak Somaya, Vermeers and Rembrandts in the Same Attic: Complementarity Between Copyright and Trademark Leveraging Strategies in Software (Feb. 23, 2006) (unpublished manuscript, on file with the Social Science Research Network), available at http://ssrn.com/abstract $=887484$ (suggesting that a complements view is more appropriate when viewing IP protection at the level of the innovation or the firm).

181. Other forms of protection include copyright, which is available for computer programs. See Apple Computer, Inc. v. Franklin Computer Corp., 714 F.2d 1240, 1246-47 (3d Cir. 1983) (source code and object code); Williams Elecs., Inc. v. Artic Int'l, Inc., 685 F.2d 870, 875 (3d Cir. 1982) (object code); Stern Elecs., Inc. v. Kaufman, 699 F.2d 852, 855 n.3 (2d Cir. 1982) (source code). Trade secret protection may also be available, generally under state law. See, e.g., Jackson v. Hammer, 653 N.E.2d 809 (Ill. App. Ct. 1995); Gonzales v. Zamora, 791 S.W.2d 258 (Tex. App. 1990); Oberg Indus. v. Finney, 555 A.2d 1324 (Pa. Super. C. 1989). 
innovations. These included: not wanting to disclose information; the cost of getting the patent, including attorneys' fees; that competitors could have easily invented around the patent; that they believed trade secret was adequate protection; the cost of enforcing the patent, including actions in court; that they did not believe the technology was patentable; and that they had no need for legal protection. ${ }^{182}$ By constructing our questionnaire in this manner, we were able to collect information on what is essentially a sample of recently un-patented major technologies generated by startup companies.

\section{A. COST CONSIDERATIONS LOOM LARGE FOR STARTUPS IN DECIDING TO FORgo PATENTING}

We find that, among technology startups, the cost of getting a patent is the most common reason cited for not patenting a major technology. Figure 4 shows the shares of reasons respondents reported for not patenting their company's last major technology innovation. ${ }^{183}$ Cost considerations in patenting loom large, with the cost of prosecuting and the cost of enforcing the patent cited by more respondents than any other reason. These motivations are followed closely by the ease of inventing around the patent. ${ }^{184}$ These results are similar to those found in a Small Business Administration survey conducted in 1998 of small firms, which listed these same reasons at the top of small-business motivations for forgoing patenting. ${ }^{185}$ In contrast, the difficulties and costs of acquiring and enforcing patents tended not to be salient for larger firms in other surveys. ${ }^{186}$ Yet, these same studies show that even in the large firm surveys, relatively smaller firms tend to report a significantly higher sensitivity to the costs of filing and enforcing patents. ${ }^{187}$

182. Our questionnaire allowed respondents to indicate multiple reasons. In a follow-on question, we asked our respondents to report which of these motivations was the most important reason.

183. This question could be answered by respondents regardless of whether they had filed for a patent. The percentages for each reason do not add up to $100 \%$ because respondents could check one or more of these selections.

184. The difference between the reported percentage for the costs of acquiring and the costs of enforcing the patent was statistically significant at a $99 \%$ confidence level. The costs of enforcing the patent and the ease of inventing around the patent did not show statistically significant differences from one another, but they were statistically significantly different from the next reported reason to a $99 \%$ confidence level.

185. JOSEPH J. CORDES, HENRY R. HERTZFELD \& NiCHOLAS S. VONORTAS, A SURVEY OF High TECHNOLOGY FIRMS 55-58 (1999), available at http://sba.gov/advo/research/ rs189tot.pdf.

186. See Cohen et al., supra note 24 , at 15-16.

187. See id. at 25 . 
Figure 4: Reasons for Startups to Forgo Patent Protection on Major Technologies

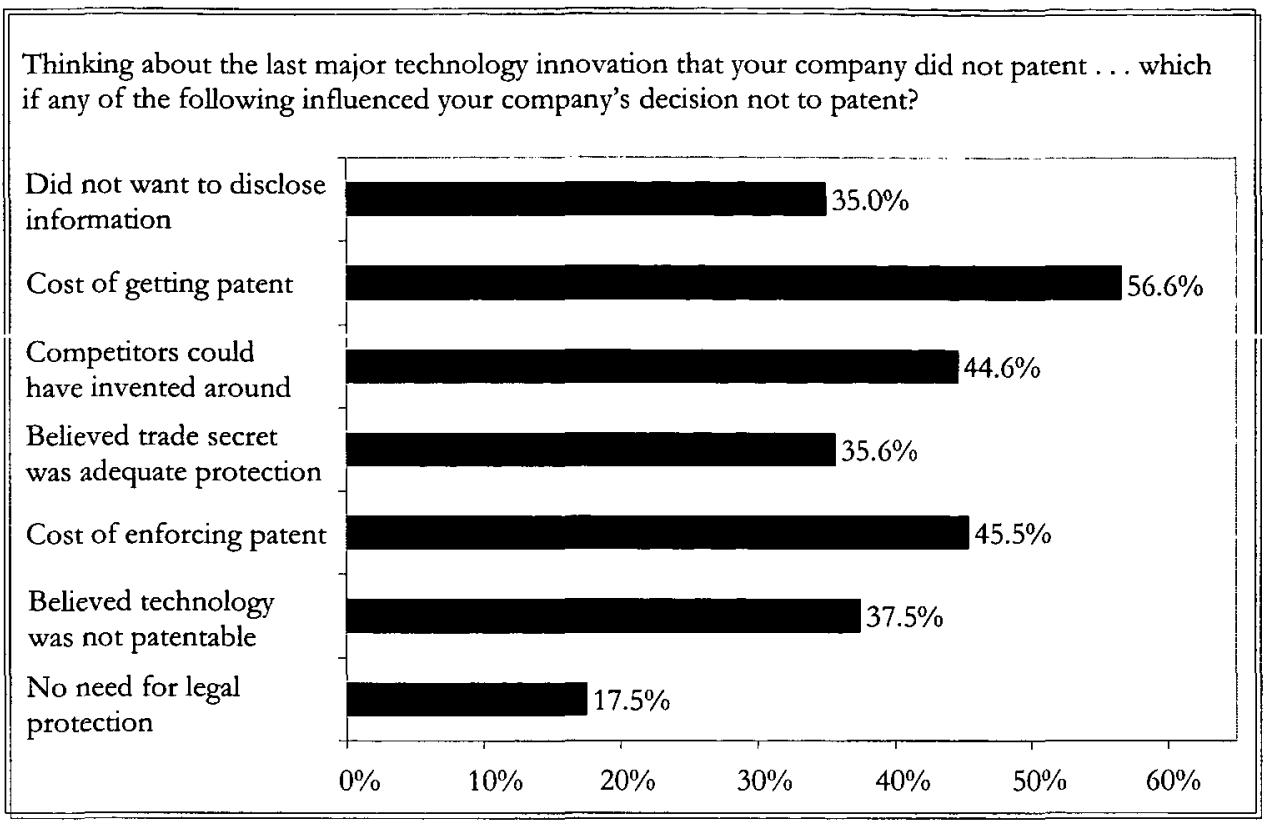

Respondents were asked to indicate all the reasons that applied (share of respondents indicating that the option influenced the decision is reported).

Other evidence from our survey results indicate that the greater sensitivity of smaller firms to costs is not merely due to capital constraints. Another of our survey questions revealed that the average out-of-pocket cost for a respondent firm to acquire its most recent patent was over $\$ 38,000 .^{188}$ This figure is significantly higher than the averages for patent prosecution reported in the literature, which vary from a low of $\$ 10,000$ to a high of $\$ 30,000$. $^{189}$ In one of the unstructured hour-long interviews we conducted with respondents, one executive at a venture-backed semiconductor firm stated that startups often pay significantly more than incumbents to their prosecuting attorneys, because startups (1) tend to file for patents on inventions that are more important to the company's core business model than large firms; (2) usually use outside instead of in-house counsel for patent prosecution; and (3) often have difficulty monitoring outside counsel to limit

188. We asked this question only of those respondents who reported that their company had both filed and been granted a U.S. patent.

189. See AM. Intellectual PRop. LAW Ass'N, Report of THE ECONOMIC SURVEY 2007 78-81 (2007) (reporting average attorneys' fees for prosecuting an original patent application, filing one amendment, and issuing an allowed application as between $\$ 10,000$ and $\$ 20,000$, depending on the complexity of the technology); Mark A. Lemley, Rational Ignorance at the Patent Office, $95 \mathrm{Nw}$. U. L. REV. 1495, 1498 (2001) (estimating the cost of prosecuting a patent to issuance as between $\$ 10,000$ and $\$ 30,000$ ). 
overall costs. ${ }^{190}$ Indeed, a non-trivial percentage of our respondents-about $10 \%$-listed cost as the only barrier to filing for a patent from among the options we offered. Additionally, when asked to indicate the most important reason for not filing, more than one-third of the respondents selected the costs of acquiring or enforcing the patent. ${ }^{191}$

Fewer respondents, but nevertheless a substantial number, reported that their firms did not seek patent protection because they considered their innovation unpatentable, believed that trade secret protection was adequate, or were reluctant to disclose information. ${ }^{192}$ These last two reasons in fact may be complementary, and may be associated with the cost considerations cited earlier. The relative infrequency of startups citing these reasons tends to track the responses by large firms in other surveys, ${ }^{193}$ although the reluctance to disclose information appears to be more of a deterrent for large firms than for our early-stage respondents. Part of this difference reflects our survey's heavy focus on software firms, whose executives less frequently cited "reluctance to disclose information" than executives of startups in other sectors. Finally, we note that about $18 \%$ of our respondents declared "no need for legal protection" as a motive for not filing a patent for their last major technological innovation.

\section{B. Startups' Reasons to Forgo Patenting DifFER By INDUSTRY}

A major finding of our study is that the most important reason that biotechnology companies cited for not pursuing a patent on their last innovation was a reluctance to disclose information, while software companies most frequently cited patent prosecution costs.

\section{Biotechnology Startups Most Commonly Cite Reluctance to Disclose Information as a Reason Not to Patent}

In an effort to better understand the drivers of startups' choices to forgo patenting on their major innovations, we segmented the responses by technology and report the results in Table 2 . We find that the most marked

190. Interview with anonymous semiconductor company executive (Feb. 20, 2009).

191. Specifically, respondents identified the following as the most important reasons for not patenting their last innovation: cost of acquiring the patent $(26.00 \%)$; did not believe technology was patentable $(20.92 \%)$; did not want to disclose information $(15.84 \%)$; ease of inventing around the patent $(12.41 \%)$; cost of enforcing the patent $(10.52 \%)$; no need for legal protection (7.33\%); and believed that trade secret protection was adequate $(6.97 \%)$. See infra Section VI.A tbl.2.

192. The responses for these reasons were not statistically significantly different from one another, but they were from the next reason-no need for legal protection-to a $99 \%$ confidence level.

193. See, e.g., Cohen et al., supra note 24; Levin et al., supra note 24. 
divergence occurs between biotechnology and software companies, and we note the differences in the share of companies that reported each motivation (along with statistical significance, in the rightmost column of the table). Biotechnology firms are more than twice as likely to cite "disclosing information" as a reason to forgo patenting as are software firms (59\% and $25 \%$, respectively). Biotechnology firms are also more likely to believe that trade secret is an adequate means of protecting their innovations than software firms ( $49 \%$ and $29 \%$, respectively), although this difference may be a consequence of the differences in the likelihood of an unpatented invention being a process technology, a possibility that we explore below.

Table 2: Reasons for Not Seeking Patent Protection - Selected Industries

Thinking about the last major technology innovation that your company did not patent... which if any of the following influenced your company's decision not to patent?

\begin{tabular}{|c|c|c|c|c|c|}
\hline نั & 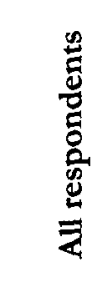 & 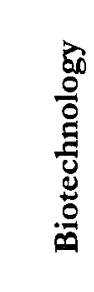 & 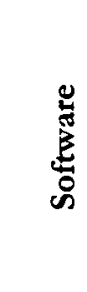 & 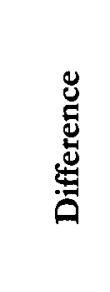 & 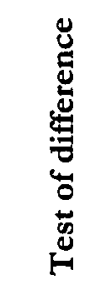 \\
\hline Did not want to disclose & $35 \%$ & $59 \%$ & $25 \%$ & $+34 \%$ & ** \\
\hline Cost of filing & $55 \%$ & $43 \%$ & $64 \%$ & $-21 \%$ & ** \\
\hline Ease of inventing around & $44 \%$ & $42 \%$ & $46 \%$ & $-4 \%$ & \\
\hline Trade secret was adequate & $36 \%$ & $49 \%$ & $29 \%$ & $+20 \%$ & ** \\
\hline Cost of enforcing & $44 \%$ & $36 \%$ & $52 \%$ & $-16 \%$ & ** \\
\hline Did not believe patentable & $38 \%$ & $28 \%$ & $42 \%$ & $-14 \%$ & *** \\
\hline Did not need protection & $17 \%$ & $17 \%$ & $20 \%$ & $-3 \%$ & \\
\hline sponses & 1,057 & 136 & 589 & & \\
\hline
\end{tabular}

** Differences noted, significant at the $95 \%$ confidence intervals. Tests for differences in means were conducted between columns, within rows.

\section{Software and Internet Startups Most Commonly Cite Cost Considerations as a Reason Not to Patent}

Patenting and enforcement costs are cited much more frequently by software and Internet firms as motives for not patenting, a finding that is consistent with the lower significance (as we report above) that software firms ascribe to patents as a means of securing competitive advantage. ${ }^{194} \mathrm{We}$

194. If the asset is considered "less valuable," sensitivity to cost may be expected to be higher. 
note that software firms were also substantially more likely to say that they did not believe that the technology was patentable than were biotechnology companies ( $42 \%$ and $28 \%$, respectively), although we are unsure whether the term "unpatentable" triggered a subjective belief in the respondent about the requirements of the patent laws or a more philosophical belief about what ought to be patentable subject matter. ${ }^{195}$

\section{The Most Important Reason Not to Patent Also Differs by Industry}

To add even greater specificity to our results, we asked our respondents to report which of the several reasons for choosing not to patent the technology was the most important. The results show that, among all respondents, the cost of filing and the belief that the technology was not patentable are most highly cited ( $25 \%$ and $21 \%$, respectively). As with many of our other results, however, there are substantial industry-specific differences.

Among biotechnology firms, over one-third (34\%) cite a reluctance to disclose information as the most important consideration, a level that is interestingly nearly matched among venture-backed IT hardware firms $(32 \%)$. These industry differences notwithstanding, the cost of filing remains a significant impediment for these startup firms, with greater than $20 \%$ of companies in each sector citing this reason as the most important determinant of forgoing patenting. This finding adds weight to other results in this survey suggesting that these technology startups are sensitive to the costs of patenting, even when patenting is seen by the executives as an important factor in their commercial and entrepreneurial success.

\section{Startups' Motives to Forgo Patenting Differ By INNOVATION TYPE}

We further explore the differences in the reasons to forgo patenting by examining whether the innovation is a product or process technology. The results suggest that the cost of applying is a particularly salient factor for those companies that chose to forgo patenting on a product technology, with nearly one-third $(32 \%)$ citing this reason as the most important factor. When firms choose to leave process technologies unpatented, they are most likely to cite three reasons about equally: reluctance to disclose information (24\%), a belief that the technology was unpatentable ( $22 \%)$, and, again, the cost of

195. See generally Pamela Samuelson \& Robert J. Glushko, What the User Interface Field Thinks of the Software Copyright "Look and Feel" Lawsuits (and What the Law Ought to Do About It), 22 ACM SIGCHI BULL. 13 (1990) (reporting survey results and finding that software engineers preferred copyright protection over patent protection). 
filing (21\%). As such, because biotechnology companies were more likely to report that their last unpatented innovation was a process innovation, part of the inter-industry differences described earlier may be explained by underlying differences in the types of technologies respondents were contemplating patenting.

\section{TECHNOLOGY ENTREPRENEURS MUST RECKON WITH PATENTS HELD BY OTHERS}

We were not only interested in determining how entrepreneurial companies use (or choose not to use) the patent system, but also how they deal with patents held by others in their market environment. When viewed as barriers to innovation, patents may create a minefield for various innovative activities, from invention, to development, to commercialization. This minefield analogy may be particularly relevant in the information technologies, to the extent that these arts are more likely characterized by innovation that is both cumulative (building on earlier generations) and complex (requiring more than one patentable technology for commercialization). Nevertheless, relying on interviews and anecdotes, Ronald Mann has suggested that patents in the competitive environment are often ignored, at least by startup software firms. ${ }^{196}$

Another downside of patents in a startup's competitive environment is the threat of patent disputes and, when negotiation fails, costly litigation. Startups may be particularly sensitive to accusations of infringement because they are likely to experience resource constraints when faced with the costs of funding a suit, estimated for most suits to be between $\$ 3$ million and $\$ 6$ million per litigant through appeal. ${ }^{197}$ Suits may come in the form of "bullying" by larger competitors trying to put the startup out of business, ${ }^{198}$ or even from "trolls" or non-practicing entities seeking royalty payments. These accusations of infringement are particularly problematic when the underlying patent being wielded against the startup is more likely than not invalid: ${ }^{199}$ the resource-constrained startup may find that its least-costly alternative is simply to pay licensing fees, thus allowing the firm to avoid suffering the huge costs of litigation-even though the patent is on its face

196. See Mann, supra note 92 , at 977.

197. See Am. Intellectual Prop. LAw Ass'N, REPort of the ECONOMIC SURVEy 2009 , at 29 (2009) (reporting that patent litigation suits with over $\$ 1$ million at stake cost roughly between $\$ 3$ million and $\$ 6$ million).

198. See Graham \& Sichelman, supra note 5, at 1080-81.

199. All patents are probabilistic rights until the last court has spoken. See Mark A. Lemley \& Carl Shapiro, Probabilistic Patents, 19 J. ECON. PERSP. 75, 75-76 (2005). 
invalid. If the litigation is launched by a "bully" attempting to put the startup out of business, the suit may indeed yield such a result if the startup is unable or unwilling to tap the capital markets to fund lengthy and expensive litigation. ${ }^{200}$

But patents in the market environment may be viewed positively by the startup, too. Patents can serve as mechanisms by which markets for technology develop, allowing some firms to specialize in a technology market in a manner analogous to Adam Smith's division of labor. ${ }^{201}$ Patents may therefore serve as a means by which technology, information, and know-how can be more easily transmitted, since there are a host of problems associated with transacting in intangible knowledge assets that patents-as-definable-chits help to solve. ${ }^{202}$ Given these discordant, but not necessarily mutually exclusive, views of the roles played by patents held by parties external to the startup, we fashioned a series of questions aimed at better understanding how early-stage companies react to patents in their competitive environment.

\section{A. LiCENSING-IN PATENTS: (SOME) STARTUPS LiCENSE FROM OTHER PATENT-HOLDERS}

We were interested in discovering how commonly startups license patents from third parties. Moreover, given the theories elucidated above, we wanted to ascertain whether, and under what circumstances, patent licenses were taken to gain technology, information or know-how, or to settle disputes. We find that among $\mathrm{D} \& \mathrm{~B}$ companies, $15 \%$ of respondents licensed-in a patent. This figure is significantly higher, over one-third $(37 \%)$, among the venture-backed sample. ${ }^{203}$ In addition to these differences among companies based on their funding source, we again find divergence based on the sector in which the company operates: in the D\&B sample, biotechnology companies are significantly more likely to license-in (37\%) than are software firms $(8 \%)$.

200. See generally CONSTANCE E. BAGLEY \& DAVID LANE, X-IT AND KIDDE (A) (2003) (detailing a startup's experience with infringement by a larger competitor, and the difficulty experienced by the startup in securing funding to pursue litigation).

201. ADAM SMITH, AN INQUIRY INTO THE NATURE AND CAUSES OF THE WEALTH OF NATIONS 12-13 (1776). Instead of some specialized employees in a pin factory making the shafts and others making the heads, the analogy would be that some firms make technology inputs like software while other firms make the technologies to which those inputs are applied, such as hardware.

202. See Ashish Arora \& Robert P. Merges, Specialized Supply Firms, Property Rights and Firm Boundaries, 13 INDUS. \& CORP. CHANGE 451, 454 (2004).

203. Difference significant at the $99 \%$ confidence interval. 


\section{Startups License Botb to Gain Knowledge and to Settle Disputes}

At least in part, the rationale for having a patent system is that by offering a limited monopoly on inventions, society will acquire more invention. ${ }^{204}$ This property right is limited in both scope and time, with the understanding that after a period of years, the patented invention will fall into the public domain and be available for all to use. In the meantime, many of the patent law's provisions are tailored to require adequate disclosure of the invention, so that other innovators may learn from the disclosure, and possibly improve upon it. ${ }^{205}$ The operation of markets for technology are also believed to help in this dissemination function-specifically, by relying on the markets to exchange patented knowledge, and thus permitting these intangible chunks of creativity to be propertized and transacted over. ${ }^{206}$

Startup firms reported that they often seek to gain knowledge, information, or know-how by licensing patents from others, yet they also indicated that they frequently-and sometimes only-license to avoid a patent dispute. When asked why their company took their last patent license, a majority of all biotechnology company respondents (81\%) indicated that they intended to gain (at least in part) technology, information, or know-how, while three in ten responded that they licensed-in the last patent (at least in part) to avoid a patent dispute, or for other defensive or freedom-to-operate considerations. ${ }^{207}$ Among the (fewer) software firms that took patent licenses, $79 \%$ reported doing so at least in part to gain information, technology, or know-how. Among both the biotechnology and software D\&B companies, less than one in ten reported that the only reason they took a patent license was to avoid or settle a patent dispute.

Among the companies receiving venture funding, biotechnology firms were again significantly more likely to in-license a patent $(72 \%)$ than were software startups $(13 \%)$. We find that nearly nine in ten of patent-licensing, venture-backed biotechnology startups declared that the last patent licensed was taken to gain (at least in part) technology, information, or know-how. Nearly two in ten of these licenses were taken (at least in part) to settle a dispute. Among the same firms, only two of sixty-three $(3 \%)$ said that the sole reason they took their last license was to avoid or settle a patent dispute. As such, our results suggest that, on average, early-stage biotechnology

204. See Arrow, supra note 4 .

205. Robert P. MERges \& JOHN FITZgerald DufFy, PATENT LAW AND POLICY: CASES AND MATERIALS 259 (3d ed. 2002).

206. See ARORA ET AL., supra note 9, at 116-17 (suggesting that intellectual property protection supports more efficient markets for technology).

207. These latter categories were self-defined by the respondents in an "other" category. 
companies are not facing demands for licensing payments on patents that are unrelated to technology that they are working upon or can foresee working upon. In general, these firms appear to be taking licenses to patents that bring some knowledge capability into the startup.

\section{Venture-Backed IT Startups Take More Patent Licenses}

We uncover that some early-stage IT companies may be more likely to face nuisance patent disputes than has been commonly reported. Among the venture-backed IT companies responding to our questions, nearly four in ten (39\%) IT hardware firms (semiconductor, communications, and computer hardware) reported taking a patent license, compared with just over one in ten $(12 \%)$ among venture-backed software firms. These patent-licensing IT hardware and software firms are almost equally likely (about seven in ten) to have taken their last patent license to (at least in part) gain technology, information, or know-how.

In a surprising result, both these types of venture-backed IT startups report that, among those that took a patent license, approximately one in four ( $25 \%$ and $22 \%$, respectively) of their last patent licenses were taken to avoid or settle a patent dispute, but not to gain technology, information, or know-how. This share is several times higher than the same figure reported by $\mathrm{D} \& \mathrm{~B}$ software companies $(8 \%)$ and by biotechnology companies $(6 \%)$ regardless of their funding characteristics.

We find this result intriguing-that a quarter of venture-backed IT firms that have taken patent licenses report that the last license was taken solely to settle a dispute, and not to gain technology, information, or know-how. In fact, these respondents did not suggest any other reasons for taking these licenses, ${ }^{208}$ but there are some caveats we must offer. While one-quarter of venture-backed software firms suggest that ending a dispute was the sole reason for taking their last patent license, the number of firms taking any patent license is quite small $(12 \%)$. As a result, only $3 \%$ of all software firms in our sample report taking their last license solely to avoid or settle a patent dispute.

But we can apply the same calculation to the hardware firms in our sample, all of which are venture-backed, and find that nearly four in ten report taking a patent license. This result shows that one in ten $(10 \%)$ of the venture-backed IT hardware startups take a patent license solely to avoid or to settle a patent dispute. We note that in contrast to the pattern exhibited by

208. Respondents were given the following choices: "For the last patent that your company licensed in, was the license taken (mark all that apply): (a) to gain technology, information, or knowhow; (b) to settle a legal dispute; (c) other [specify]." 
biotechnology firms, these figures associated with settling a patent dispute are much higher for venture-backed IT firms than among their (generally non-venture-backed) D\&B software counterparts. ${ }^{209}$

What is behind this increased likelihood of venture-backed IT firms facing threats of litigation? The unstructured hour-long interviews that we conducted with a sample of our respondents produced one story of just such a patent dispute. One executive of a venture-backed IT company informed us that his firm had been the target of a cease-and-desist letter during the company's initial SEC Registration prior to its IPO. He believed the patent was invalid, and that it was simply a nuisance suit aimed specifically at the firm at a time when they were most vulnerable-precisely when the executives were trying to convince investors in their IPO "road show" that the company offered a solid investment opportunity. ${ }^{210}$

Anecdotes like this one offer a possible explanation for the pattern that we find. Specifically, that one-tenth of venture-backed IT hardware firms may be paying royalties for a patent license that provides no beneficial knowledge or information raises questions about the operation of the "market for patents" as a knowledge exchange mechanism. We surmise that the higher share of licensing merely to avoid suits among IT firms may be the consequence of several influences: a combination of the type of innovation and the nature of the firm's funding.

It is well accepted that information technologies are different from biochemistry innovations. ${ }^{211}$ While the latter are termed "discrete" technologies for which a single patent can often adequately protect the entire invention, the former are characterized as "complex" technologies in which many separately patentable inventions are commonly needed to commercialize a product. ${ }^{212}$ Complex technologies have been theorized to increase the transaction costs associated with commercialization, ${ }^{213}$ and the problems associated with clearing patent rights are well-documented. ${ }^{214}$ There

209. This difference between venture-backed and D\&B IT company responses is significant at the $95 \%$ confidence interval. Statistically, there is no difference between the biotechnology results for the D\&B and venture-backed firms ( $8 \%$ and $4 \%$, respectively).

210. Interview with anonymous executive (Apr. 2009).

211. See Cohen et al., supra note 24, at 19. But of. Arti Rai \& James Boyle, Synthetic Biology: Caught Between Property Rights, the Public Domain, and the Commons, 5 PLOS BIOLOGY 389 (2007), available at http://www.plosbiology.org/article/info:doi/10.1371/journal.pbio.0050058 (discussing a convergence of these technologies).

212. Cohen et al., supra note 24 , at 19.

213. See Michael A. Heller \& Rebecca S. Eisenberg, Can Patents Deter Innovation? The Anticommons in Biomedical Research, 280 SCI. 698, 699 (1998).

214. See James Bessen \& Michael J. Meurer, Patent Failure: How Judges, BUREAUCRATS, AND LAWYERS PUT INNOVATORS AT RISK 69-70 (2008). 
are also claims from engineers that, at least in the software fields, many of the patents issued since the 1980 s have been on trivial inventions. Patented technology considered trivial coupled with the complex nature of the technology (and a liberal injunction rule) lends itself to hold-up and could result in the pattern we observe.

But the "venture funded" characteristic of these firms also appears to be playing a role in this difference. We note that the types of software companies we surveyed from $\mathrm{D} \& \mathrm{~B}$ are able to operate generally free of the threats that appear to be at the heart of our finding. The venture-funding event is an important one in the life of a startup, and is often publicizedcommonly by the startup itself because it provides a positive signal of quality to other investors, competitors, and consumers alike. Moreover, commercial research firms (such as Thomson) collect and report on these investments. Therefore, a startup's venture-funding event is news, and it may raise the profile of the company sufficiently to make it a target for holdup of the type we describe above. Companies that are venture funded are also more likely to have other significant liquidity events like IPOs or high-value acquisitions and mergers: these too may increase the potential pay-off to patent holders external to the firm when threatening these startups with infringement. While this hypothesis is intriguing, a fuller understanding must await further research.

\section{B. Checking the Patent Literature by Startups: Mixed FINDINGS}

Another little-understood aspect of operating in an environment with patents concerns the propensity and timing of patent searching by innovators. When we consider the goals of the innovator and society, there are substantial benefits that may flow from searching the patent literature. Because innovation is often cumulative, the cost of innovation for both the innovator and society may be reduced when greater information about the current state of the technology is easily discoverable by the innovator. Moreover, to the extent that the underlying subject matter is a complex technology that is "modular," searching the patent literature may allow the innovator to find existing inputs to its ongoing creative process, thus preventing duplicate innovation that tends to squander society's resources. ${ }^{215}$ By searching the patent literature, innovators may also avoid the risk of investing in $R \& D$ ex ante only to discover that they cannot practice the inventions ex post due to existing and blocking patent rights.

215. We speak here of duplicate efforts on the same composition, method, or processit may be that different means could be used to reach the same outcome. 
While these benefits suggest that searching the patent literature may be efficient and desirable, it has been suggested that entities may actually shy away from conducting searches. ${ }^{216}$ Specifically, the patent system may have unintentionally created disincentives to patent searching, because doing so can expose the searcher to the risk of liability for willful infringement. ${ }^{217}$ Under the existing patent laws, entities that are aware of existing patent rights and engage in willful infringement can suffer treble damages. ${ }^{218}$ This rule has led to advice from attorneys that companies should not do searches at all. (However, the continuing viability of such advice has been cast into doubt by recent case law. ${ }^{219}$ ) Moreover, searches may be expensive in both money and time, and in new and embryonic technology areas, or ones that are very general in application, there may be added difficulty in discovering the proper scope for patent searching. ${ }^{220}$

Accordingly, we were interested in discovering which way these conflicting incentives might cut. We therefore inquired whether our respondents' companies regularly check the patent literature to determine if someone else has a U.S. patent that covered what they were doing or were considering. For those respondents answering "yes," we also asked at what stage of commercialization the company usually conducts that search: prior to design; during design and development; after launch; or (notably out of temporal order) only when the firm was planning to apply for a patent.

A substantial share of the respondents to this question reported regularly doing patent searches. Among D\&B respondents who answered, slightly more than one-third reported conducting these searches. This likelihood was particularly high for biotechnology (nearly seven in ten) and medical device (over half) companies, while slightly less than one-quarter of software companies reported doing regular patent searches.

Among the venture-backed sample, searching was substantially more common. Among all the respondents to this question, nearly six in ten venture-backed firms reported that they regularly searched the patent literature. Again, this propensity was particularly high among biotechnology (nearly nine in ten) and medical device (over nine in ten) firms. Nevertheless, nearly three in ten venture-backed software startups and over six in ten similarly funded IT hardware companies reported doing so. This finding is

216. See BESSEN \& MEURER, supra note 214 , at 70 .

217. See id.

218. See 35 U.S.C. $\$ 284$ (2006).

219. See In re Seagate Tech., L.L.C., 497 F.3d 1360 (Fed. Cir. 2007) (en banc) (adopting a rule making it more difficult for plaintiffs to show "willful infringement").

220. See BESSEN \& MEURER, supra note 214 , at 69-72. 
notable, because it casts doubt on previous anecdotal evidence that venturebacked software companies, by and large, do not perform patent searches. ${ }^{221}$

Our findings on the timing of searches are also noteworthy given that companies may face conflicting incentives. Because these searches are costly (both in terms of money and technology employees' time), and given that these small startups are resource constrained (both in terms of money and time), it would stand to reason that at the margin, companies would tend to delay these searches, if not put them off altogether. Conversely, to the extent that effective patent search is an information input into the innovation and technology planning processes, early search might yield greater benefits, especially to technology startups for which technical information is critical for both ongoing innovation and effective competition.

We find that those startups that do patent searches tend to conduct them relatively early in the commercialization process. Among the $D \& B$ population of companies, $65 \%$ report usually doing searches prior to product or process design, and $70 \%$ report that these searches are usually done during design and development. ${ }^{222}$ We may have also uncovered an element of patent strategy associated with this searching among our respondents: $14 \%$ report usually conducting examinations only when the company is planning to apply for its own patent (an event that may occur early or late in the commercialization process).

It is also noteworthy that one-third of the companies that conduct searches report usually doing so only after commercial launch. This result raises the possibility, consistent with our finding on patent licensing, that it is not uncommon for threats or other competitive information to arrive only after product launch. Since the company's technology is likely to be most notorious after product launch, it is conceivable that the company's competitors, or those interested in collecting royalties from the company, would be most active at that point. It is also possible that some companies

221. See Mann, supra note 92 , at 1004. Mann states,

For one thing, none of the startup firms to which I spoke suggested a practice of doing prior art searches before beginning development of their products. As far as I can tell, the only occasion in the software industry in which a startup is likely to experience such costs is when the startup is founded on a specific piece of existing technology spun off from an existing company or from a university laboratory.

Id.

222. These percentages can sum to more than $100 \%$ because respondents were allowed to mark more than one category when identifying at which stage the company "usually" conducted the patent search. 
put off costly searching until they are more certain of the economic value of a technology-a certainty that may only come to light after product launch.

A similar pattern surfaces for the respondents in our venture-backed sample. For these companies, nearly six in ten relate usually doing searches prior to product or process design, with three-quarters reporting that these searches are usually done during design and development. Like the D\&B companies, one-third note that the company usually searches the patent literature only after commercial launch, while nearly one-quarter report that they usually conduct examinations only when planning to apply for their own patents. But, because venture-backed firms are more likely to hold patents, ${ }^{223}$ it may be that this increased share influences the higher likelihood among venture-backed firms to do searching at all when compared with the $D \& B$ respondents, fewer of which hold patents. That there may be a "patent feedback mechanism"-with startups engaged in patenting also being more likely to examine the patent literature-is an interesting possible finding of our study deserving further research.

\section{IS THE PATENT SYSTEM WORKING FOR U.S. TECHNOLOGY STARTUPS?}

Our evidence suggests that for startup companies, by and large, the patent system is neither working well, nor poorly. We asked our respondents one purely attitudinal question, without a specific definition: "Overall, how well is the U.S. patent system working . . for your company," and "for your industry?" We offered the respondents five options, including "very well," "well," "neither well nor poorly," "poorly," and "very poorly." We had few expectations about what answers this question would yield, although we hypothesized that given the ongoing debate over the utility and validity of many software patents that we would see answers from software companies skewed toward the poorly end of the scale. Moreover, we were particularly interested to see whether the responses from startups would exhibit an essentially "U-shaped" distribution, with answers populating disproportionately the polar ends of the scale, with many answering "very well" and others answering "very poorly," with few in the center. Such a bimodal distribution of answers would raise the possibility that our respondents were self-selecting into our survey based on how passionate they felt about the patent system, whether they had a "love" or a "hate" attitude toward it.

223. See supra Part III. 
In fact, we find that the responses to both questions essentially took a classic bell-shaped form, with a mean and mode around the central answer. This result suggests that executives in early-stage technology startups in the United States find that the patent system, whether they are considering their company or their industry, is working neither well nor poorly. In essence, they appear in general to believe that the patent system is "muddling through."

There are some inter-industry differences in these responses, but the deviations are not as great as we surmised they would be at the project's inception. For instance, over $35 \%$ of respondents from the biotechnology industry answered that the patent system is working "well" or "very well" for their company, but the most common answer (the mode of the distribution) is still the central answer, "neither well nor poorly." Among software companies, the most common answer (the modal answer) is again the central answer, with over $55 \%$ of the respondents selecting this middle choice. ${ }^{224}$

Surprising to us was the opinion among these startups that the patent system is generally working less well for their industries than for their companies. Among the biotechnology companies for example, the pattern for "how well is the patent system working for your industry" is the mirror image of the answers to the "company" question. The mode was the same (the central answer), but over $35 \%$ of the respondents said they believe the patent system is working "poorly" or "very poorly" for their industry. Given that patenting in the "discrete" technology of biotechnology is usually held out as an example of how well the U.S. patent system is operating, this shared opinion among these biotechnology executives raises more questions than it answers. Software and Internet executives' answers are virtually identical on the "industry" question to those of the biotechnology responses, with the most common answer in the center of the choices, but over $35 \%$ of respondents indicating that the patent system is working "poorly" or "very poorly" for their industry.

Therefore, executives from both the D\&B sample (essentially drawn from the population of early-stage technology companies in the U.S.) and the $V$ entureXpert sample of high-quality, venture-backed firms are saying, at best, that the patent system is neither working poorly nor well. At worst, they

224. It is worth speculating whether these respondents were prone to the "central answer" bias reported elsewhere in the literature on surveys, although this same phenomenon did not seem to dominate their answers on other questions. See generally Eric A. Greenleaf, Improving Rating Scale Measures by Detecting and Correcting Bias Components in Some Response Styles, 29 J. MARKETING RES. 176 (1992) (finding bias when using certain configurations of response scales). 
sense it is working poorly for their companies and their competitors. Such a finding does not bode well for our system. In the opinion of this "entrepreneurial class"- arguably one of the key drivers of innovation in the United States-the patent system does not appear to be functioning particularly well.

\section{CONCLUSION}

By conducting a reasonably comprehensive survey on the relationship of the U.S. patent system to technology entrepreneurship, we have attempted to fill an important gap in the considerable body of work exploring intellectual property and more generally, innovation. Notably, our detailed results do not offer simple answers to this inquiry. For instance, we discover that technology startups are generally more likely to file for patents, as well as hold greater numbers of patents, than was previously believed. But we also reveal that these same companies report that patents provide mixed to relatively weak incentives for core innovative activities, such as invention, development, and commercialization. Part of the foregoing analysis attempts to uncover the motives for technology entrepreneurs acquiring and filing patents when those patents-according to the judgment of those same entrepreneurs-do not offer particularly strong innovation incentives.

Our response to the questions raised by these discordant streams has been both nuanced and multifaceted. We report that a large share of startups, especially in the software industry, opt out of patenting altogether. Although startups appear to be more aggressively accessing the patent system than previously reported, we find that these effects reflect our survey's ability to measure difficult-to-capture patent holdings. Specifically, our survey includes the reported number of patents originating from founders, acquisitions, and filed patent applications, rather than merely the number of patents recorded for a given firm name at the Patent Office. As such, we do not believe our larger numbers reflect an upward shift in filing rates among startups in the past several years.

We also report that for many startup companies, patents are an important part of the mix of strategies used by them to capture competitive advantage from their technology innovations. But this important role tends to be much more pronounced among biotechnology and "hardware" companies (including both medical hardware such as surgical devices, and IT hardware, such as computers and semiconductors) than among software and Internet startups. In fact, we find that for software and Internet companies, patents generally serve a much less important function in almost all of the entrepreneurial activities about which we surveyed. 
These disparate findings trumpet a major result of our study: the industry in which a startup operates tends to exert a strong influence on the role that patents play in the firm's entrepreneurial activities. This finding may be driven by underlying technology differences in these sectors, variation in industrial organization, or other unseen factors. The deep differences we find in the use and utility of patents by startups across industries tracks many of the patent reform debates of recent years, and while some of the understanding that flows from those debates is useful in explaining our results, we find that startups can be quite different from their larger counterparts in their patenting behavior. As such, more research into the drivers of these industry differences at the level of the startup is needed.

This Article also demonstrates profound differences in the manner and extent to which patents are used by venture-backed companies. In a related series of findings, we report that patents are useful to startups in attracting entrepreneurial capital and for improving the likelihood of a successful exit event (such as being acquired or going public). In an important new showing, we demonstrate that patenting may play a previously underappreciated and important role in helping startups to secure investment from various sources, including "friends and family" and commercial banks, as well as angel investors and venture capital-although these results, too, are contextspecific. These findings may partly explain why venture-backed startups are generally more apt to use patents, and consider them important, since our evidence suggests that these companies have been "selected" upon by VC investors for their patents. But here too, more study is needed to uncover the dynamics of the patent-financing relationship in technology entrepreneurship.

Our survey also reports why technology entrepreneurs use the patent system. Contrary to some previous anecdotal accounts, those firms that file for patents report that they do so primarily to prevent others from copying their products and services. Additionally, our study is the first to suggest that startups use patents in strategic ways, such as to improve bargaining positions in cross-licensing deals and defend against infringement suits. This finding undermines the previously held belief that the strategic uses of patents are significant motivations only for larger-firm patenting.

Finally, we find that our respondents believe, by and large, that the patent system is not working particularly well for their companies or their industries, even in the fields of biotechnology, medical devices, and computer hardware, where our survey suggests patents are considered to be more useful for a range of reasons. Because many studies have shown that entrepreneurs and their firms play a substantial role in driving innovation, employment, and 
economic growth, we strongly believe that further study is warranted to determine how the system might be reformed to better serve the needs of startups.

In the meantime, following on this Article, we plan to further explore our dataset in a series of more focused articles. These foci include the drivers of patenting by entrepreneurs, patenting among software and Internet startups, patents in entrepreneurial "markets for technology," the effects of patents in allowing startups to enter new markets, and the relationship of patenting to market valuation and exit, among others. In sum, we plan to use our dataset to study a host of topics shedding additional light upon the role that patenting is playing in technology entrepreneurship.

We thank Robert Barr, Executive Director of the Berkeley Center for Law and Technology (BCLT), for his consistently helpful comments and unflagging support in making this survey project a success. We received beneficial insights from our project's Advisory Board (Hank Barry, John Barton, James Bessen, Tom Ciotti, Wesley Cohen, John Duffy, Rebecca Eisenberg, Brad Feld, John Freeman, Richard Gilbert, Michael Goldberg, Bob Gunderson, Bronwyn Hall, Mitchell Kapor, Peter Menell, Mark Myers, James Pooley, Walter Powell, Arti Rai, AnnaLee Saxenian, Carl Shapiro, Robert Strom, Lee Van Pelt, and David Yoffie), and from Peter Ang, Brian Broughman, Colleen Chien, Jesse Fried, Dietmar Harhoff, Bob Litan, Gladys Monroe, Bob O'Connor, Sheridan Paulker, E.J. Reedy, Alicia Robb, F.M. Scherer, and John Walsh. We also thank participants at the 2008 Berkeley Technology Law Journal Symposium on Patenting and Entrepreneurship, the 2008 Kauffman Foundation Symposium on Entrepreneurship and Innovation Data, the 2008 OECD-DIME Patent Statistics for Managers Conference, the 2009 OECD-Kauffman Workshop on Entrepreneurship and Innovation, the National Bureau of Economic Research's Summer Institute 2009, the 2009 Conference on Empirical Legal Studies, the 2009 IP Scholars Conference, the 2009 Creativity, Law, and Entrepreneurship Workshop at the University of Wisconsin Law School, the 2009 Kauffman Foundation Summer Institute, the 2009 Northwestern Law School Searle Center Conference on the Law and Economics of the Entrepreneur, the 2009 West Coast Research Symposium, the 2009 Works in Progress in Intellectual Property Conference, and faculty workshop participants at the Bar-Ilan School of Law, DePaul Law School, Georgia Tech College of Management, Harvard Business School, Stanford University Economics Department, and the University of California, Berkeley, Haas School of Business and School of Law. We thank Galen Hancock for working closely with us as our chief research assistant since the inception of the project, and David Grady and Louise Lee for administrative support. We acknowledge helpful advice from Bob Lee and UC Berkeley's Survey Research Center, and research assistance from Peter Dimitrov, Andrew Harris, Deepak Hegde, Christine Rhyu, Erin Trimble, Stephen Ullmer, and Brian Weissenberg. This research was funded by the Ewing Marion Kauffman Foundation. The contents of this article are solely the responsibility of the grantees/authors. All errors and omissions are our own. 
